\title{
Criminal Procedure Entitlements, Professionalism, and Lawyering Norms
}

\author{
DARRYL K. BROWN*
}

\begin{abstract}
This Article explores how social norms affect lawyers' and judges' behavior and, thereby, the content of both legal entitlements and the practice of ethics. It draws from several large studies of local criminal law practice that, until now, have not been used in legal scholarship. Norms in law practice often conflict with legal entitlements. Yet the Article argues that such norms sometimes are defensible and necessary responses to tensions in public values and conflicts between policymaking institutions; they identify the need for doctrinal change, rather than changes in law practice. In other instances, however, norms neither reconcile such conflicts nor devise efficient options to formal rules. Given agency problems in law practice, norms sometimes are rent-seeking actions by lawyers and judges. In addition, they are driven by lawyers' and judges' ideological commitments; norms serve personal visions of just outcomes and fair procedures. Finally, because lawyers observe norms that conflict with formal entitlements-leading them explicitly to disavow or subvert rules-norms reveal how notions of professionalism are revised to accord with actions that undermine both client interests and public values. Focusing on the link between lawyering practice and doctrine, the Article suggests ways courts can respond to norms, and it surveys strategies for reforming undesirable norms.
\end{abstract}

\section{INTRODUCTION}

One way to describe how attomeys practice law is to say that clients present sets of facts and circumstances, and attorneys look to substantive and procedural law for options that will best achieve the client's objectives. Attorneys may need to help clients clarify objectives-goals may evolve as attorneys highlight legal options and implications for clients' nonlegal concerns. Of course, attorneys are then limited only by financial resources and rules of professionalism.

This is the traditional vision implicit in legal education as well as in rules of legal ethics; lawyers consider all legal options and provide zealous representation within the available budget. ${ }^{1}$ The picture is in an important sense one of a blank

* Assistant Professor of Law, Washington \& Lee University School of Law. This Article benefited both from insightful comments by my colleagues Barry Sullivan and Lash Lanue, who read earlier versions of the manuscript, and from spirited discussions in faculty workshops at Washington \& Lee, the University of Florida, and the University of Denver law schools. I am grateful to the Sydney Lewis Law Center for research support.

${ }^{1}$ One can refine the picture by noting the skill that comes with experience; veteran practitioners may know informal means to achieve client goals. See WLIIAM H. SIMON, THE PRACTICE OF JUSTICE: A THEORY OF LAWYERS' ETHICS 45-46 (1998) (describing the "dominant view" of lawyer advancing client interests); see generally What Lawyers Know: 
slate on which the lawyer chooses among all formal legal options and perhaps some informal ones. For that reason, the picture is inadequate. Lawyers do not practice on a blank slate; they practice in contexts. Contexts include not only the circumstances in which client problems arise or the dynamics of the attomeyclient relationship ${ }^{2}$ but also the legal community. Some practice contexts drastically constrain the options-including legal entitlements-realistically available to attorneys, greatly influence their judgment about which strategies are available, and significantly affect client counseling. They also change the effective content of legal rules.

This description builds on the premise that has found broad application in social science and, more recently, in legal scholarship: social organization and, in particular, community norms are almost always more important influences on individual conduct than formal rules. In criminal justice policy, scholars including Tracey Meares have built upon social organization theory to suggest that law enforcement can more effectively address criminal conduct by focusing more on norms than rules-by strengthening "social control through the generation... of effective community norms" because norms affect conduct more than formal rules. ${ }^{3}$ More broadly, social organization theorists have studied a wide variety of social contexts to build the thesis that individual preferences are shaped by institutional settings. Norms take on a rule-like status and define the acceptable ways to make routine judgments; although they are contingent upon social practices, they often seem driven by material imperatives. ${ }^{4}$ Finally, a corresponding interest in behavioralism has gained significant attention in legal

Lawyering Expertise, Cognitive Science, and the Functions of Theory, 45 J. LEGAL EDUC. 313 (1995) (discussing attomeys' assessments of multiple factors in strategic decisions).

2 See, e.g., DAVID A. BINDER ET AL., LAWYERS AS COUNSELORS 4 (1991) (noting that lawyers need both "industry knowledge," referring to the circumstances in which clients' problems arise, and "extralegal knowledge," arising from clients' varying 'knowledge, emotion and sophistication" and readiness to make decisions, in order to devise effective solutions from legal principles).

3 Tracey L. Meares, Place and Crime, 73 CHI.-KENT L. REV. 670 (1998); see also id. at $669,670-77$. Similarly, recent empirical work on delinquency, studied at the neighborhood level, explains the causes of "legal cynicism" (meaning anomie or disillusion about law) and accompanying law-breaking behavior by structural characteristics of the community rather than looking only to individual-level beliefs or choices. See generally Robert L. Sampson \& Dawn Jeglum Bartusch, Legal Cynicism and (Subcultural?) Tolerance of Deviance: The Neighborhood Context of Racial Differences, 32 L. \& SOC'Y REV. 777 (1999).

${ }^{4}$ See Paul J. DiMaggio \& Walter W. Powell, The Iron Cage Revisited: Institutional Isomorphism and Collective Rationality in Organizational Fields, 48 AM. SOC. REV. 147, 147-51, 157 (1983); John W. Meyer \& Brian Rowan, Institutionalized Organizations: Formal Structure as Myth and Ceremony, 83 AM. J. Soc. 340, 341-47, 355-59 (1977); Lynne G. Zucker, The Role of Institutionalization in Cultural Persistence, 42 AM. Soc. REV. 726, 727 28 (1977). 
scholarship that helps explain the operation of norms and offers compatible insights on how decisionmaking is affected by context. 5

This Article describes how those insights apply to lawyers as they make professional decisions in practice, particularly in state criminal courts. In localized, close-knit practice settings, lawyers and judges often adopt strong social norms. This Article will call them practice norms because they govern law practice. On crucial issues, attorney judgment is affected by norms that coerce or persuade attorneys to choose options they would not otherwise choose, for reasons other than the client's best interest. Entitlements that formally exist for clients-discovery rights, expert witnesses, jury trials - can be unavailable in practice. Legal professionals effectively rewrite substantive and procedural entitlements granted by case law or legislation.

Examining law practice through the lens of social norms provides a perspective for two related projects. The first posits that practice norms provide implicit critiques of rules or doctrines and the feasibility of some entitlements. This Article argues that despite their conflict with formal law and client interests, practice norms are not per se a bad development. Rather, practice norms can serve as a useful form of critique for formal entitlements.

Many entitlements, such as the right to a jury trial in misdemeanor cases, are created by judicial decision. Yet the real availability of that formal right depends on the support of the executive and legislative branches. ${ }^{6}$ Trial judges and lawyers must respond to higher-level institutional choices. In doing so, they sometimes sub rosa revise legal entitlements. Legislatures, commissions, and appellate courts set rules that practitioners evaluate and reject or accept in light of conditions in which those rules operate-material constraints, justice considerations in specific cases, and player self-interest or ideological

5 Behavioralism generates theories of decisionmaking that raise implications for doctrine and practice in such areas as contract negotiation and products liability. See, e.g., Jon D. Hanson \& Douglas A. Kysar, Taking Behavioralism Seriously: Some Evidence of Market Manipulation, 112 HARV. L. REV. 1420 (1999) (products liability); Russell Korobkin, Inertia and Preference in Contract Negotiation: The Psychological Power of Default Rules and Form Terms, 51 VAND. L. REV. 1583 (1999) (contract negotiation) [hereinafter Inertia and Preference]; Russell Korobkin, The Status Quo Bias and Contract Default Rules, 83 CORNEIL L. REV. 608 (1998) (same).

${ }^{6}$ Recent work recognizing dynamic relationships between institutional actors has provided important insights on the limited efficacy of appellate review as a means of social change or rule creation without legislative support. See generally William N. Eskridge, Jr., Overriding Supreme Court Statutory Interpretation Decisions, 101 YALE L.J. 331 (1991) (statutory interpretation); Michael J. Klarman, Brown, Racial Change, and the Civil Rights Movement, 80 VA. L. REV. 7 (1994) (civil rights); William J. Stuntz, The Uneasy Relationship Between Criminal Procedure and Criminal Justice, 107 YALE L.J. 1 (1997) (criminal procedure rights). 
commitments. Norms confront the same trade off between fairness and efficiency that occurs at the level of doctrine and statutes. In some instances, norms are defensible responses based on information more readily available to trial-level actors than to appellate courts or legislators. Sometimes, however, they are unreliable critiques of rules, because of lawyers' and judges' ability (due to agency problems) to serve their own interests or ideological preferences. In both cases, norms strike different trade offs than public lawmaking. This distinction in norms' functions and legitimacy yields a taxonomy of practice norms (presented in Part III) that maps which norms are amenable to change by local lawyers and which, conversely, appellate courts should take as signals to re-examine rules.

The second project here, a response to recent literature of lawyer professionalism, is raised by the first. This Article suggests that practice norms often lead to lawyering that is problematic under either model of the two prominent approaches to lawyering ethics-William Simon's recent book-length development of his ethical discretion thesis, and competing approaches that urge a more client-centered commitment, represented by Stephen Pepper and David Binder. Practice choices are in great part products of local contexts. Norms demonstrate how local work settings lead attorneys to construct very different models of law and lawyering, which affect both doctrine and client interests. ${ }^{7}$ Practice norms shape the content of professionalism notions. Its socially contingent nature explains why professionalism does not overcome norms that conflict with formal rules and reflect self-interested action by lawyers or judges (even though most are concerned with their reputations). ${ }^{8}$

Legal scholarship gives ample attention to the purported effects of legal rules but too little attention to contextual factors that affect lawyer judgment as well as court decisions. The conjunction of these two projects offers a way to integrate analysis of typically separate topics: lawyering and doctrine. At the level where doctrine is put in practice, the two are inseparable. Lawmakers, including courts, must look to practice to assess the feasibility of doctrine; practice defines the working content of substantive, procedural, and ethical rules, which are often in sharp contrast to formal statements.

This project looks at norms as they affect aftormeys' strategic judgments for

${ }^{7}$ See Robert L. Nelson \& David M. Trubek, Arenas of Professionalism: The Professional Ideologies of Lawyers in Context, in LAWYERS' IDEALS/LAWYERS' PRACTICES 177, 188 (Robert L. Nelson et al. eds., 1992).

${ }^{8}$ Economic analyses of lawyering tend to ignore the possibility that professionalism could constrain self-interested action. See, e.g., Pamela S. Karlan, The Path of the Law Firm: A Comment on Ribstein's "Ethical Rules, Agency Costs, and Law Firm Structure," 84 VA. L. REV. 1761, 1766-67 (1998) (criticizing Ribstein for discounting ethical commitments and suggesting they can have a substantial effect); Larry E. Ribstein, Ethical Rules, Agency Costs, and Law Firm Structure, 84 VA. L. REv. 1707, 1715 (1998). 
individual clients and claims. ${ }^{9}$ To do so, this Article relies on recent empirical studies of courts that have received little attention in legal scholarship ${ }^{10}$ as well as more anecdotal accounts of trial-level criminal law practice, primarily from appellate opinions. This Article proceeds in several parts. Part II reviews the concept and definition of norms, especially in recent legal scholarship. Building on empirical research of courts and law practice, this Article introduces several examples of practice norms that undermine zealous representation, client interests, and public values. It then identifies two functions that practice norms serve-efficiency and justice. The former has received much attention in legal literature, the latter relatively little. Part III analyzes several specific practice norms for their varying implications for parties, attorneys, and doctrine. Then, relying on recent scholarship on lawyering ethics, Part IV describes how norms often mislead attorneys from their ostensible professional roles and thereby undermine the key interests they should serve-client preferences and public interests.

Part V explores why norms retain such influence by looking at several explanations for their persistence, which include behavioral theory, ideological trends toward nonadversarial processes within the formal justice system, and agency problems in the attomey-client relationship. This Article links practice norms to criticisms of Alternative Dispute Resolution (ADR) and managerial judging, which are other informal substitutes for formal adjudication that, like norms, pose special risks for low income litigants. Finally, Part VI considers the wide variation in practice norms among comparable settings-the phenomenon of legal pluralism - to explore the possibilities of reducing or reforming undesirable norms and encouraging preferable ones. Concluding remarks explore the level of responsibility lawyers bear for perpetuating norms even though their construction of norms is not always deliberate or fully voluntary.

\section{DEFINING AND EXPLAINING PRACTICE NORMS}

\section{A. What Are Norms?}

Legal scholars, following longer standing work by social scientists, have

${ }^{9} \mathrm{Cf}$. Nelson \& Trubek, supra note 7, at 188 (urging "contextual examination of microencounters in different... settings" for a "complete account of the social construction of professionalism").

${ }^{10}$ In addition to published studies, I was granted access to a primary data set consisting of extensive interviews with attomeys and judges from a jurisdiction with a relatively close-knit professional community. This archive is part of the largest empirical study of criminal courts to date, conducted by Eisenstein, Nardulli, and Flemming. I am grateful to Professor Eisenstein for arranging my access to the archive. See infra note 13 (documenting little use of these studies in legal scholarship). 
given increasing attention to the role of norms in law, particularly the insights norms can bring to economic analysis of law. ${ }^{11}$ Legal studies focus on how norms affect behavior and dispute resolution among wide varieties of groupsvoters, merchants, ranchers, and employers. ${ }^{12}$ Yet legal norms scholarship has thus far given no attention to how norms affect legal professionals and the adjudication process, despite a wealth of empirical research on law practice and local courts that documents lawyers' and judges' behavior. ${ }^{13}$

Norms, strictly defined, refer not merely to widely observed and repeated conduct (say, that most people sleep at night) nor merely to widely shared values or customs. Rather, they describe conduct that is either encouraged by rewards or enforced by sanctions. ${ }^{14}$ In this sense, norms are rules, which are violated only at a cost. Norms are most likely to arise (and to be most effective) in relatively small groups who have regular, repeated interaction with each other, so that they possess both information about past behavior and future opportunities to impose sanctions or rewards. ${ }^{15}$

It is well known that norms exist in some practice contexts-especially state and local courts, in both large cities and smaller towns. ${ }^{16}$ Every lawyer who

11 Recent legal interest in norms is probably attributable in large part to Robert C. Ellickson's influential book, Order Without Law. See ROBERT C. ELLICKSON, ORDER WITHOUT LAW (1991); see also Symposium, Law, Economics, \& Norms, 144 U. PA. L. REV. 1643 (1996).

12 See generally ELLICKSON, supra note 11 (ranchers); Lisa Bernstein, Merchant Law in a Merchant Court: Rethinking the Code's Search for Immanent Business Norms, 144 U. PA. L. REV. 1765 (1996) (merchants); Richard L. Hasen, Voting Without Law?, 144 U. PA. L. REV. 2135 (1996) (voters); Edward B. Rock \& Michael L. Wachter, The Enforceability of Norms and the Employment Relationship, 144 U. PA. L. REV. 1913 (1996) (employment).

13 That inattention is part of a broader deficit in legal scholarship to take account of the substantial empirical research on lawyers, courts, and other legal practice settings. The largest data set of its kind-a study of nine criminal court jurisdictions by Nardulli, Flemming, and Eisenstein (on which this Article relies)-is a key example. A 1999 . Westlaw search reveals no legal scholarship has more than referenced the work without comment in a footnote. Search of Westlaw, JLR Library (May 12, 2000).

${ }^{14}$ See ELLICKSON, supra note 11, at 123-26; Robert D. Cooter, Decentralized Law for a Complex Economy: The Structural Approach to Adjudicating the New Law Merchant, 144 U. PA. L. REV. 1643, 1656 (1996); Richard H. McAdams, The Origin, Development, and Regulation of Norms, 96 MICH. L. REV. 338, 350-51 (1997).

15 See ELLICKSON, supra note 11, at 177-82, 238; see also PETER F. NARDULLI ET AL., THE TENOR OF JUSTICE 124 (1988); MCAdams, supra note 14, at 386-91 (contrasting groupbased norms, which arise among tight-knit groups, and societal norms).

16 See Roy B. Flemming ET AL., THE CRAFT OF Justice 10 (1992) (describing how "grapevine" gossip helps "enforc[e] norms" in courthouse communities); id. at 137 (describing "[c]ourthouse communities" as tight-knit "[t]hickets of informal relations"); MITON heumanN, Plea BargainING: The EXPERIENCE of PROSECUTORS, JUdges, aND Defense 
practices in such a setting - where she frequently appears before the same judges or deals with the same group of attomeys-can describe local customs and practices, some of which amount to norms. Moreover, practice in local court communities, particularly criminal courts, has been extensively studied by social scientists. ${ }^{17}$ Norms that especially undermine client interests, however, are unevenly distributed among practice settings and client groups; practice norms hurt some parties more than others.

Because norms operate at the "ground level" of law practice in local settings, data are hard to gather. ${ }^{18}$ For a flavor of the norms at issue here, consider some illustrations. ${ }^{19}$ A well-known example is the norm against jury trials. Empirical studies $^{20}$ and anecdotal accounts from practice ${ }^{21}$ confirm that jury trials are an

ATTORNEYS (1975); NARDULLI ET AL., supra note 15, at 124, 376. There are several extensive studies of attomeys in state court criminal practice settings that document norms, customs of practice, and common patterns of lawyering conduct. There are substantially fewer such studies in either the context of civil practice or elite, federal court practice for wealthy clients. But see generally HERBERT M. KRTIZER, THE JUSTICE BROKER: LAWYERS AND ORDINARY LITIGATION (1990) (presenting data from Civil Litigation Research Project); KENNETH MANN, DEFENDING WHITE COLLAR CRIME (1985) (presenting a study of elite attomeys who represent wealthy defendants in white-collar, mostly federal, criminal cases); see also KENNETH KRESSEL, THE PROCESS OF DIVORCE 159 (1985) (describing the "professional dilemma" that "while the official code of conduct prescribes a zealous pursuit of the client's interests, the informal norms and the realities of professional life prompt compromise and cooperation").

17 While the goals of those studies vary, they often describe practice norms that are widely followed and enforced by attorneys and judges. Heumann's study of Connecticut criminal courts, for example, was designed to study how novice attomeys adapt to plea bargaining practices designed by experienced practitioners, who radically revise new graduates' conceptions of appropriate practice. See HEUMANN, supra note 16, at 1-7.

${ }^{18}$ See KRITZER, supra note 16, at vii, 123 (noting even the well-funded Civil Litigation Research Project, based on extensive attomey surveys and interviews along with a variety of quantitative analyses of cases and outcomes, had "virtually no specific information on" how relationships among clients, courts, and other attomeys might affect "the details of the [work] content of ... various" lawyering activities, including settlement negotiations and discovery). Cf. Diane Vaughan, Rational Choice, Situated Action, and the Social Control of Organizations, 32 L. \& Soc'Y REV. 23, 53 (1998) (noting that attempts to study the related problem of decisionmaking within institutions face the same problems of gathering data because "interviewees may not be able to articulate many of the factors that affected their actions"). While Flemming, Eisenstein, and Narduli's extensive study of criminal courts gathered notable examples of practice norms, norms were not the primary focus of the research, and attomeys and judges are likely to under-report such norms.

19 The focus of this Article will be criminal practice settings because the empirical data from those contexts is much more extensive than that for civil practice, but throughout it will suggest some analogies and applications for civil practice where possible.

20 See, e.g., HEUMANN, stupra note 16; NARDULU ET Al., supra note 15; David Lynch, The Impropriety of Plea Agreements: A Tale of Two Counties, 19 L. \& SOC. INQURY 115 (1994). 
infrequent form of case resolution not solely for legitimate reasons, such as the parties freely reaching a plea or settlement. Jury trials are also suppressed by judges and attorneys - backed by sanctions against attorneys and litigants-who disapprove of them in certain contexts and who express that disapproval openly. 22

Norms may also govern the resources and procedures committed to trials. Under Ake v. Oklahoma, ${ }^{23}$ indigent parties have a due process right to obtain funds from the court for expert assistance. Lower courts in many jurisdictions have not limited this right to serious crimes, yet trial courts sometimes regulate access to Ake funds through a norm. Consider demands for Ake funds for experts to challenge breath-test results supporting misdemeanor DWI charges. ${ }^{24}$ (The test can be inaccurate on some people, which is especially important in close cases.) A trial judge may feel compelled by case law to grant the funds requested. However, a judge still can chill the exercise of that right by, say, more harshly sentencing defendants who exercise the right but later lose the trial. ${ }^{25}$ This chilling signals local attorneys to exercise the right more judiciously than the doctrinal language suggests. ${ }^{26}$

${ }^{21}$ I can offer a number of such examples from my former practice as a public defender. Upon announcing a jury demand in one case, the judge-who had little if any more information about the case than the indictment-responded, "no, no, no, we're not going to have a jury trial in this case." In another instance, while supervising a law student intern representing a defender client, a judge responded to the student's jury trial demand with a phone call to inform me that, if we proceeded with the jury demand, the price would be that he would require me, rather than the student, to try the case. See infra note 260 (discussing student Michael DeFibaugh's account of jury trial rights in a municipal court).

22 This norm is explored in more detail below. See infra Part III.C.3.

23470 U.S. 68, 83 (1985) (defining a due process right for indigent defendants to expert assistance for issues that are "significant factors" in a criminal trial).

${ }^{24}$ See, e.g., Elmore v. State, 968 S.W.2d 462 (Tex. App. 1998). This example is based on my own experience as a public defender.

${ }^{25}$ As discussed below, judges have other sanctions available as well, such as discretion in appointing counsel to criminal cases. See infra note 41 and accompanying text. Also, note that a prosecutor could seek to enforce the same norm by recommending a higher-than-normal sentence. $C f$. NARDULLI ET AL., supra note 15 , at 151 (describing public defenders who routinely waive an entitlement for a physician examination in a mental competency hearing).

${ }^{26}$ Another example I observed in one locality is a norm against Sixth Amendment challenges to jury venires. A group of public defenders noticed that the venires summoned for jury duty were suddenly very unrepresentative (all senior citizens in one pool, all low income African-Americans in another, nearly all affluent whites in a third, always from the same neighborhoods). The motion was fully plausible on the doctrine, and the issue implicated an important client as well as public interest in representative juries. Yet local judges reacted with hostility, insisting the matter should be handled informally, although that would entail doing several trials with unrepresentative juries. When the defenders declined to withdraw the 
Another well-documented norm conflicts with a seeming prerequisite of zealous practice-filing defense discovery motions in criminal cases. In his account of criminal practice in several Connecticut state court localities, Milton Heumann notes widespread pressure on new attomeys not to file discovery motions or bills of particulars, although new attorneys (trained in formal rules from law school) are strongly inclined to do so. The norm in these court communities, which experienced attorneys (particularly prosecutors) taught to new attomeys with a combination of rewards and sanctions, was for the prosecutor to employ an "open file policy" for defense attorneys who declined to file discovery motions. New attorneys who filed motions faced a variety of punishments, from warnings to withdrawal of "open files," stingy plea bargain offers, and court date scheduling inconveniences. 27

Local practice communities often have many such norms. Judges may discourage formal hearings on the record. ${ }^{28}$ Certain evidence rules may be so consistently ignored that attorneys give up attempting to enforce the rules with objections, so as to avoid judicial disapproval. ${ }^{29}$ Randall Kennedy has noted an

challenge, some judges resorted to classic norm sanctions: they verbally warned defenders of negative implications ("You've ruined your reputation in this courthouse."), and then imposed docket changes to create scheduling conflicts and other burdens. Judges complained of one attomey to the state bar (without consequence) and led a successful effort to have the defenders evicted from their courthouse office space. (It tumed out that the county's computer system that used to draw names from voter lists for jury duty had malfunctioned; it began to pull names nonrandomly, all from the same zip code areas.) See Interviews with Lynn Koeller and Tim Young, Public Defenders, in Montgomery County, Ohio (Spring 1997) (I served as a consultant to the defender office in this jury litigation).

27 See HEUMANN, supra note 16, at 52-91.

28 See, e.g., In re Inquiry Concerning Judge Damron, 487 So. 2d 1, 3 (Fla. 1985); Gwartz v. Superior Court, $71 \mathrm{Cal}$. App. 4th 480 (Cal. Ct. App. 1999). The appellate court in Gwartz reprimanded "a handful of judges on the local superior court bench" who refused parties an opportunity for oral argument on summary judgment motions despite what the appellate court here describes as clear case law mandating oral argument. Id. at 481-82. The trial judges' practice suggests a typical norm that undermines a formal rule to serve what the judges view as efficiency, although it undercuts public and party interests in procedures that aid at least the appearance of due process if not substantive outcomes.

${ }^{29}$ As one such example from civil practice, Sarat and Felstiner report an attomey's view that evidence rules barring testimony of a divorce party's alleged adultery in certain contexts are uniformly ignored, so that attorneys learn to forgo objections to such testimony. See AUSTIN SARAT \& WILIAM L. F. FELSTINER, DIVORCE LAWYERS AND THEIR CLIENTS 96-97 (1995). This account includes no mention of sanctions or rewards to enforce the norm, so that it may be more in the nature of a custom, which is widely followed but not enforced by punishments. It is likely, however, that judges perpetuate this custom with at least mild sanctions, such as expressions of annoyance at attomeys who should know the objection is useless. Repeated refusal might bring harsher sanctions. See id. at 99 (reporting that one attomey advised his client, "'you can really prejudice the judge against you by bringing up 
historical example of another norm regulating zealous motions practice: social and professional sanctions on white lawyers who challenged exclusion of black jurors. ${ }^{30}$ Local attorneys and judges may have customs of ex parte discussions of cases, an objection to which may meet a sanction of negative gossip or diminished cooperation. In many local jurisdictions, rules on ex parte communication $^{31}$ are honored only sporadically; it is not uncommon for attorneys to discuss cases substantively with a judge in chambers without opposing counsel being present. ${ }^{32}$ In one case study in which attorneys reported such ex parte contacts to be routine, an attomey made the rare response of filing a motion to disqualify the judge. He reported that he encountered "all kinds of flack" and was "forced [by his boss], under the threat of firing [him], to send an apology to the judge because [he] had acted, according to [the judge], in an unprofessional manner." ${ }^{33}$ (Tellingly, the attorney was new to the locality. Informal sanctions quickly taught the local norm. $)^{34}$ The same norm apparently exists in civil practice contexts in some localities ${ }^{35}$ although not in others. ${ }^{36}$

As the examples indicate, lawyers and judges enforce practice norms with informal sanctions. As is typical in other settings, such as Robert C. Ellickson's study of ranchers, ${ }^{37}$ sanctions typically begin with verbal warnings or negative

certain issues in a certain way"').

30 See RANDALL KENNEDY, RACE, CRIME, AND THE LAW 174 (1997).

31 See MODEL CODE OF JUdICIAL CONDUCT Canon 3B(7) (2000); see also Phoebe Carter, Annotation, Disciplinary Action Against.Judge for Engaging in Ex Parte Communication with Attorney, Party or Witness, 82 A.L.R.4th 567 (1990) (collecting rules and cases). The Code has been adopted by many states. See, e.g., CONN. CODE OF JUDICIAL CONDUCT 3(a)(4) (1998).

32 See, e.g., FLEMMING ET AL., supra note 16, at 32; In re Inquiry Concerning Judge Damron, 487 So. $2 \mathrm{~d}$ at 5 (depicting a trial judge arguing his ex parte contacts are justified because "in a rural county ... this type of communication is common").

33 FLEMMING ET AL., supra note 16, at 156.

34 See id.

35 See Judith Resnik, Managerial Judges, 96 HARV. L. REV. 374, 387, 390, 425, 427 (1982) (noting that federal judges' increasing managerial role has led them to hold separate meetings with parties to encourage settlement and gain information through such contacts that may affect their decisions).

My colleagues who practice in local courts through a law school legal clinic report observing similar widespread, routine instances of ex parte contact between judges and opposing attomeys in civil cases. Though they have at times joined those conversations, without invitation, when they encountered them in progress (thereby eliminating their ex parte nature), they report never raising formal complaints about them nor hearing of other attomeys who have done so.

36 See, e.g., FLEMMING ET AL., supra note 16, at 113, 130 (noting a judge who bars ex parte contacts in criminal cases).

${ }^{37}$ See ELLICKSON, supra note 11, at 209-10. 
gossip and then may escalate to more serious punishments. ${ }^{38}$ Attorneys and judges have a wide variety of tools for punishing norm violations. Studies of local courts and practice settings are rich with examples. Negative gossip is invariably documented as a sanction, ${ }^{39}$ as is public chastisement. ${ }^{40}$ Judges may have the power to withhold or increase court appointments of both criminal and civil cases (such as guardianships). ${ }^{41}$ Judges (and sometimes prosecutors) may have the power to create scheduling inconveniences for an attorney's court appearances. ${ }^{42}$ Sanctions can also include adverse rulings, such as an increased sentence for defendants who lose at trial after forgoing a plea offer or insisting on Ake funds.

Attorneys also have means to employ sanctions against one another.

38 See, e.g., HEUMANN, supra note 16, at 62 (noting prosecutors' use of multiple sanctions against defense attorneys who file discovery motions, typically starting with an explanation of the norm to "steer [the new attomey] straight," then escalating to "'hassling," "dragging the case out over a long period of time, closing all files to the attomey, and even threatening to go to trial on the case"); id. at 63 (stating that a sanction may include a less favorable plea bargain offer for the defendant); see also ELLICKSON, supra note 11, at 214-19 (stating that the first remedial norm group members resort to is typically the weakest or least drastic-typically, it is gossip or verbal warning); NARDULII ET AL., supra note 15, at 127 (describing "cordiality norms" that govern "the appropriate responses to those who violate norms," such as making the client "suffer," withholding cooperation, curtailing court appointments, or trying to fire the attorney). Similarly, a key procedural norm is a duty to transmit information to other members that help minimize internal disputing (typically, one assumes, information about the content of substantive norms). See id. at 230 . Attomeys and judges typically transmit such information and wamings especially to new attomeys (or to newly deviant attorneys).

${ }^{39}$ References to gossip and widespread information exchange are pervasive in the empirical literature. See, e.g., FlEMMING ET AL., supra note 16, at 10; HEUMANN, supra note 16; NARDULLIET AL., supra note 15.

40 See FlEMMING ET AL., supra note 16, at 28, 55-56.

41 See id. at 125-26, 138 (finding that in one jurisdiction "judges doled out masters and guardianships"); id. at 150 (expressing a judge's statement: "[i]f you go to trial on every single case, you're not gonna get the appointments"); id. at 151 (describing judges who barred the renewal of an indigent defense contract to a group of attomeys whose litigation seemed excessive); Alison Frankel, Too Independent, AM. LAW., Jan.-Feb. 1993, 67, at 68 (discussing proposals to remove judges' power to appoint federal public defenders to reduce judges' power to retaliate for aggressive advocacy); see also Caplin \& Drysdale v. United States, 491 U.S. 617, 647 (1989) (Blackmun, J., dissenting) (describing zealous attomeys who may "displease a judge" and "influence the judge's appointment decisions"); SARAT \& FELSTINER, supra note 29 , at 106 (showing an attomey informing a client that because "'the judge has been appointing me on all the guardianship and guardian ad litem cases... maybe that is a sign that he likes me... [and] inclined your way anyway"').

42 See FLEMMING ET AL., supra note 16, at 33-34 (criminal); id. at 69-70 (civil dockets); HeUManN, supra note 16, at 52-91; PETER F. NARDULLI, THE COURTROOM ElTTE 153-61, 181-85 (1978). 
Prosecutors can withhold favorable plea bargain terms from uncooperative defense counsel and discretionary favors such as open file discovery. ${ }^{43}$ Civil attorneys can be similarly uncooperative in discovery and settlement proceedings. Criminal defense attorneys typically have the fewest sanctions in their arsenal but may nonetheless be capable of exercising rights to transfer a case to another judge or of responding with refusals to stipulate to evidence or to waive procedural entitlements. 44 Superiors can give office subordinates unappealing case assignments. ${ }^{45}$ Less obviously, judges sometimes have means to make fellow judges observe norms; for example, managing judges control other judges' dockets and work conditions. ${ }^{46}$

The sanction of negative gossip and verbal reprimand is potent in close-knit law practice settings, because attomeys place considerable importance on their reputations. ${ }^{47}$ Reputation and credibility are a form of social capital that can make a substantial difference to the attorney's material well-being. Poor reputation may invite informal sanctions such as reduced court appointments and private referrals. ${ }^{48}$ Further, it can make the attorney less effective for clients, because it may reduce her ability to work with opposing counsel and judges who expect norm compliance. Reputation, then, is a powerful mechanism for influencing cooperative behavior ${ }^{49}$ and, along with other, informal enforcement

43 See generally State v. LaForest, 665 A.2d 1083 (N.H. 1995). The LaForest court held that it is not a due process violation for a prosecutor to condition a plea bargain offer on the condition that the defendant not undertake further discovery. See id. at 1087. The prosecutor's practice reveals the sort of informal sanctions (made available by doctrines like this due process rule) that prosecutors can use to enforce norms against exercising formal entitlements. In this rape case, the prosecutor had turned over a large amount of evidence but conditioned the offer upon the defendant not seeking the results of a "rape kit" medical exam or deposing witnesses, both of which were important to defendant's defense of absence of penetration. Sze id. at 1086-87.

44 See FLEMMING ET AL., sUpra note 16, at 73; EDWARD HUMES, NO MATTER HOW LOUD I SHour 285-92 (1996). Of course, use of such sanctions may carry a risk that they will be countered with more severe responses.

45 See FLEMMING ET AL., supra note 16, at 49, 56-57.

46 See LAWRENCE BAUM, THE PUZTLE OF JUdiCIAL BeHAVIOR 35 (1997).

47 See FLEMMING ET AL., supra note 16, at 65-66, 89, $139-44$.

48 See Donald D. Landon, Clients, Colleagues, and Community: The Shaping of Zealous Advocacy in Country Law Practice, 1985 AM. B. FouND. RES. J. 81, 99 ("Business getting involves meticulous... maintenance of reputation.... Although the norms guiding the evaluation are local, and not necessarily professional, the accountability is thorough and effective."). "[T]he smaller community, with its more intense scrutiny and discussion of its members' conduct and its greater ability to mobilize consensus... (including clients and cases), becomes a formidable source of sanctioning." Id. at 111; Ribstein, supra note 8 , at 1714-15.

${ }^{49}$ See ELLICKSON, supra note 11, at 232. 
tools, for forcing attomeys to take account of norms.

\section{B. Functions of Practice Norms}

\section{Self-Interest and Efficiency Rationales}

Scholars have offered several theories of the origin of norms..$^{50}$ In his influential book, Order Without Law, Ellickson defends a central hypothesis about the function of norms. "[M]embers of a close-knit group develop and maintain norms whose content serves to maximize the aggregate welfare that members obtain in their workaday affairs with one another." ${ }^{1}$ Norms encourage cooperation among group members who have the option of adversarial or other noncooperative conduct, especially in non-zero-sum contexts in which cooperation will yield mutual gains. Groups use norms to set a standard of ordinary or expected behavior. ${ }^{52}$ Just as ranchers or orchard owners ${ }^{53}$ can be deemed a "bad neighbor" subject to sanctions, an attomey who creates excessive work and disruption deemed unnecessary may face sanctions. ${ }^{54}$ Generally, then, economic and public choice approaches suggest that norms facilitate cooperation among group members and diminish deadweight losses to the group's objectively measured aggregate welfare..$^{55}$ Norms often establish informal social contracts to solve collection action problems and to supply collective goods..$^{56}$

Participants often perceive norms as products of necessity. ${ }^{57}$ Attorneys and

${ }^{50}$ See McAdams, supra note 14 , at 339-54.

51 EuLCKson, supra note 11, at 167.

52 Ellickson's thesis accords with empirical studies of courts that stress the use of norms to serve self-interest. See, e.g., NARDULLI ET AL., supra note 15, at 377 (concluding from an extensive study of state criminal courts that norms will endure and "act as check upon individual actors" as long as they "serve[] the interests and needs of the courtroom actors").

53 See Steven N. S. Cheung, The Fable of the Bees: An Economic Investigation, 16 J.L. \& ECON. 11, 29-30 (1973) (considering the custom of beekeeping by rural orchard owners).

54 See, e.g., HEUMANN, supra note 16, at 61 (noting prosecutors resented standard discovery motions by defense attorneys as "an unwarranted waste of time"). Of course, ranchers and orchard owners are principals, while attorneys are agents. See infra Part V.D.1.

55 See EuLCKsON, supra note 11, at 172, 241. Note that this is objectively measured welfare. The inadequacy of objective measurements are well known. See, e.g., Richard H. Pildes, The Unintended Cultural Consequences of Public Policy: A Comment on the Symposium, 89 MICH. L. REV. 936, 937, 955-66 (1991) (presenting a problem especially relevant for attomey-client contexts, which is addressed below); see also infra Part IV.A.

56 For a discussion of how the social meaning of norms solves collective action problems, see Lawrence Lessig, The Regulation of Social Meaning, 62 U. CHI. L. REV. 943, 956-58 (1995).

${ }^{57}$ See Paul J. DiMaggio \& Walter W. Powell, Introduction to THE NEW 
judges in some settings are so pressed by scarce resources that they cannot fully utilize costly entitlements. ${ }^{58}$ In litigation settings, practice norms typically help conserve court and attorney (and sometimes, client) resources by forgoing claims and procedures for which there are cheaper, informal substitutes. Examples may include prosecutor open file policies instead of discovery motions; ex parte or informal negotiations with judges instead of motions practice; 59 and pleas instead of jury trials. Because formality is usually more costly than informality ${ }^{60}$ norms help avoid procedures not perceived as cost-justified by the professional community, such as appeals of adverse rulings in minor misdemeanor cases. ${ }^{61}$

Practice norms, however, are often problematic as efficient substitutes for formal legal and professional rules, partly for reasons public choice scholars recognize. First, unlike many settings that have been the focus of norms studies, legal practice involves an agency relationship, and norms developed by lawyers and judges sometimes impose agency costs on clients. Attomeys and judges may have strong incentives to minimize use of formal procedures and entitlements if informal processes save them resources, and parties cannot assess what benefits they lose from forgoing formality. ${ }^{62}$ In the jargon of public choice theory, practice norms sometimes are rent seeking. ${ }^{63}$ Further, the utility variables used to

INSTITUTIONAIISM IN ORGANIZATIONAL ANALYSIS 10-28 (Walter W. Powell \& Paul J. DiMaggio eds.) (1991) (discussing how human behavior in institutional settings is constrained and influenced by conventions that shape preferences and make some options appear necessary when they are in fact optional).

58 The same justification has been offered for ADR. See Judith Resnik, Many Doors? Closing Doors? Alternative Dispute Resolution and Adjudication, 10 OHo ST. J. ON DISP. RESOL. 211, 246 (1995); Stuntz, supra note 6, at 32-37.

${ }^{59}$ See, e.g., In re Inquiry Conceming Judge Damron, 487 So. 2d 1, 5 (Fla. 1985) (describing a trial judge who argued, in a disciplinary proceeding, that his ex parte contact with counsel was justified by the "heavy county court docket" and because "this type of communication is common"); see also supra note 26 (discussing Ohio trial judges' pressure on public defenders to forgo constitutional challenge to unrepresentative jury pools).

60 This does not mean formality is not cost-justified, but that calculus may depend on valuing subjective benefits and utilities, which cannot be done objectively. See infra notes 158-59.

61 See FLEMMING ET AL., supra note 16, at 150-51.

62 Risks for clients arise in the determination that informal arrangements fully substitute for formal processes and do not discount client values or impose other externalities on clients. Even if an attorney informs a client of the likely sanction for violating a norm-insising on a trial in the face of a possible trial penalty-the norm still burdens the client's decision whether to exercise the entitlement. Further, attomeys make many norm-based decisions without consulting the client.

${ }^{63}$ Cf. David Chamy, Illusions of a Spontaneous Order: "Norms" in Contractual Relationships, 144 U. PA. L. REV. 1841, 1848, 1851 (1996) (discussing contexts in which, under public choice theory premises, some groups seem likely to create inefficient norms that 
assess efficiency here are especially "soft" and difficult to quantify. They include clients' nonmonetary preferences and public values implicated in public adjudication ${ }^{64}$ (both of which are addressed in more detail below).

Second, legal pluralism belies an explanation of norms that relies solely on resource constraints and professionals' self-interest. Within comparable practice settings-such as local criminal courts with roughly comparable dockets, budgets, and staffing - there exists wide variation in practice norms. Some locales have more formal discovery, more trials, and stronger traditions of aggressive advocacy. Such pluralism (and thus, practice norms) is more fully explained by reference to informal justice commitments and the ideological function of norms. Finally, norms studies in the legal literature rarely deal with actors who are governed by formal ethical codes, and public choice theory does not have good tools to explain how actors reconcile self-interested action with professionalism commitments. ${ }^{65}$ Norms revise the professional rules themselves, which presents normative rather than efficiency issues. ${ }^{66}$

\section{Norms as Justice Standards}

Practice norms serve a second function that helps justify their content and reconcile their apparent conflict with professionalism rules. Norms serve practitioners' conceptions of substantive justice and procedural fairness, including views about which entitlements clients really deserve, even if those views contradict formal rules.

Psychological research has found that fairness concerns have an effect in explaining behavior and attitudes toward courts and public institutions

favor concentrated, interested groups over diffuse ones).

${ }^{64}$ Law has normative goals-equality, corrective justice, individual rights, procedural faimess-independent of efficiency. See ELLICKSON, supra note 11, at 206; id. at 169-70 (citing Jim Crow segregation as one example of a norms regime that benefitted insiders at a substantial cost to those outside the group). Assessments of efficiency are thus problematic, because the assessment requires identifying what case outcomes law seeks to produce efficiently, and that requires a qualitative judgment. See Resnik, supra note 35, at 395, 420-21; Resnik, supra note 58, at 225-28.

The same problem affects cost-benefit analysis more broadly in regulatory policymaking. See Pildes, supra note 55, at 955-56 (discussing understatement of "soft" variables in policymaking). For an influential argument on the public values at stake in adjudication over private settlement, see Owen Fiss, Comment, Against Settlement, 93 YaLE L.J. 1073, 1085-87 (1984).

65 See Karlan, supra note 8, at 1766-67.

66 Cf. NARDULLI ET AL,, supra note 15, at 126 (describing variation in criminal court communities, with some emphasizing efficiency and others seeking goals of disinterested professionalism). 
independently of self-interest motivations. ${ }^{67}$ Once professionals arrive at a consensus on which rights litigants are really entitled to, or what conduct is really professional, practice norms incorporate those justice notions and in turn are justified by them. Because a norm seems fair and right, its conflict with a formal rule is less objectionable. 68 This accords with the more general conclusion that people feel a moral obligation to obey norms because they internalize the moral content of the norm. ${ }^{69}$ Norms provide the functional content of professionalism as well as legal rules. Norms in this sense "subsidize" breaches of formal ethical or legal rules; they make it easier to do so by substituting professional-group approval for what otherwise should be dissonance between the norm's content and professional or legal rules. ${ }^{70}$

For a vivid example, recall the attorney who raised a complaint about ex parte contacts. ${ }^{71}$ His objection was deemed "unprofessional." Not only is complicity in ex parte contacts considered consistent with professionalism, refusal to comply is labeled unprofessional. The working conception of professionalism is fully reversed from the formal standard and vigorously enforced without the slightest cognitive dissonance.

Two related lines of empirical literature support the idea that justice sentiments underlie norms. First, the recent literature on commonsense justice, which focuses on criminal law, suggests that, on a range of substantive law issues, popular sentiments differ from criminal codes and doctrine. Many people

67 See Tom R. Tyler et al., Alternative Images of the Citizen: Implications for Public Policy, 41 AM. PSYCHOLOGIST 970, 973 (1986).

68 This point is relevant to the argument over whether norms are efficient. If professionals value procedural entitlements for elite litigants more than those for low income litigants, norms that displace those entitlements are less likely to seem cost-effective. This hypothesis may suggest an avenue for refining much of empirical findings on procedural justice, which suggests that elites place more emphasis on procedural justice than average citizens. See Robert J. Boeckmann \& Tom R. Tyler, Commonsense Justice and Inclusion Within the Moral Community: When Do People Receive Procedural Protections from Others?, 3 PSYCHOL., PUB. POL'Y \& L. 362, 376 (1997). Observations of law practice suggest that legal professionals employ some of the same distinctions, or at least that one finds such attitudes in the less elite sectors of the bar-those attorneys and judges who work in local courts with large numbers of low income parties.

${ }^{69}$ See Robert D. Cooter, Against Legal Centrism, 81 CAL. L. REV. 417, 426-27 (1993) (reviewing ELLICKSON, supra note 11). For an example, see HEUMANN, supra note 16, at 86 (describing an attomey's accommodation to a trial penalty norm by his stating, "I think substantial justice is worked out a good percentage of the time; you kind of reach the right results for the wrong reasons.").

${ }^{70}$ See Cass R. Sunstein, Social Norms and Social Roles, 96 CoLuM. L. REV. 903, 934, 940 (1996) (discussing how norms may "tax[ ]" or "subsidiz[e]" choices).

71 See FlEMMING ET AL., supra note 16, at 156 (discussed supra at notes 32-34 and accompanying text). 
think, for example, that accomplices should be punished less harshly than principal perpetrators, especially in felony murder crimes. At least in mock jury studies, those sentiments affect verdicts despite contrary legal rules. ${ }^{72}$ Other studies recount examples of legal professionals allowing popular sentiments to inform discretionary judgments. Traffic court judges sometimes fashion a rough justice by dismissing tickets of undisputed violators because the burden of having to come to court is deemed sufficient punishment. ${ }^{73}$ Trial judges have actively subverted civil rights and criminal procedure entitlements created by Supreme Court decisions. ${ }^{74}$

Second, extensive research on procedural justice suggests that perceptions of procedural fairness have significant effects, independent of substantive outcomes, on how one assesses legitimacy of courts and decisionmakers. ${ }^{75}$ Commitments to fair procedures vary with the context and the claim or rights at issue. $^{76}$ In the criminal context, support for jury trials and complex

72 See NORMAN J. FINKEL, COMMONSENSE JUSTICE: JURORS' NOTIONS OF THE LAW 159 71 (1995) (drawing conclusions from mock juror studies); see also Paul H. Robinson \& John M. Darley, JUSTICE, LIABLITY AND BLAME: COMMUNTTY VIEWS AND THE CRIMINAL LAW 1351 (1995); $c f$. CASS R. SUNSTEIN ET AL., DO PEOPLE WANT OPTIMAL DETERRENCE? (University of Chicago Law School John M. Olin Program in Law \& Economics Working Papers No. 77, 2d Sers., 1999) (stating that strongly held moral intuitions may undercut opposing legal rules or policies) (available electronically at <http:/www.law.uchicago.edu/Publications/Working/ ndex.html > (visited May 11, 2000).

73 While that rough justice strikes judges as substantively fair, it bothers many litigants as procedurally unfair. See E. ALLAN LIND \& TOM R. TYLER, THE SOCIAL PSYCHOLOGY OF PROCEDURAL JUSTICE 2 (1988). As further examples, note that some state trial judges openly concede their choice to inform their judgments, at least where law is ambiguous, with community values or popular local sentiment, including endorsement of plea bargains that treat accomplices less severely than principals. See generally ROBERT A. CARP \& C.K. ROWLAND, POLICYMAKING AND POLITICS IN THE FEDERAL DISTRICT COURTS (1983) (finding, based on empirical research, that judicial attitudes-including personal values and regional customsinfluence judges' decisions); FLEMMING ET AL., supra note 16, at 125 (showing a judge chastising a prosecutor for refusing to treat an armed robbery defendant less severely than the principal perpetrator "even though the individual in this case was just a tagalong"); Lief H. Carter, How Trial Judges Talk: Speculations About Foundationalism and Pragmatism in Legal Culture, in LEGAL HERMENEUTICS: HISTORY, THEORY, AND PRACTICE 219, 228 (Gregory Leyh ed. 1992). Prosecutors divert their limited resources away from enforcement of laws that seem antiquated and of little social value. $C f$. William $\mathrm{H}$. Simon, Ethical Discretion in Lawyering, 101 HARV. L. REV. 1083, 1091 (1988) (describing how prosecutors and other legal actors, in addition to juries, effectively nullify applications of centain laws).

${ }^{74}$ See, e.g., GERALD N. ROSENBERG, THE Hollow HOPE: CAN COURTS BRING ABOUT SOCIAL CHANGE? 89 (1991).

75 See Tyler et al., supra note 67, at 975 .

76 See Boeckmann \& Tyler, supra note 68, at 363. 
decisionmaking procedures increases with the severity of the crime. ${ }^{77}$ Support for fair procedures also varies with the type of crime and with instrumental concerns, such as the perceived threat a suspect poses. ${ }^{78}$ People also discriminate in their attitudes toward procedural faimess based on symbolic or relational concerns, meaning that those who are outside one's social group or seemingly pose a threat to shared community values are viewed as deserving less procedural faimess than those closer to one's group or values.79

Practice norms reflect the same procedural justice attitudes. ${ }^{80}$ Most of the norms at issue here involve procedural protections. Trials, funds for experts, limits on ex parte contact, and formal discovery are processes designed to improve substantive outcomes by increasing information, reducing bias, or opening the process to public scrutiny. Following this research, one would expect lawyers and judges to honor formal entitlements to jury trials or expert assistance more in murder trials than misdemeanors but less when the accused is poor or otherwise from a marginal community (when the "social distance" between lawyer and litigant is greater). ${ }^{81}$ Furthermore, it is apparent that lawyers feel

77 See id. at 364.

78 See id. at 363-64.

79 See id. at $363-65,367,372,377$.

${ }^{80}$ Arguably, many criminal courts expend more resources for procedure in capital cases-more readily funding experts, for example, or tolerating extensive pretrial motion practice. The horror stories of inadequate capital defense counsel and inadequate funding of defense, however, demonstrate that the claim at best applies unevenly across jurisdictions. See Steven Bright, Counsel for the Poor: The Death Sentence Not for the Worst Crime but for the Worst Lawyer, 103 YALE L.J. 1835, 1837-44 (1994); cf. HERBERT MCCLOSKY \& ALIDA BRIL, DIMENSIONS OF TOLERANCE: WHAT AMERICANS BELIEVE ABOUT CIVIL LIBERTIES 13670, 232-73 (1983) (finding that political and legal "elites" place greater emphasis on civil rights and due process than others).

For suggestions that state and local judges are relatively responsive to popular sentiment, see, for example, Carter, supra note 73, at 228 (concluding from discussions with state trial judges that "[w]hen confronted with an ambiguity in law, these judges imagined themselves both capable and empowered to resolve the ambiguity... by opting for that choice which better fit their vision of community values and experiences'); Steven P. Croley, The Majoritarian Difficulty: Elective Judiciaries and the Rule of Law, 62 U. CHI. L. REV. 689, 727 (1995). Carter recounts one judge's statements as representative:

[M]ost of the time you reach a result that's fair and then build your thinking around it.... We disregard precedents, but we sure try to avoid reversals.... [T] where I say to myself, 'Well, the precedent is on all fours, but I think it's wrong, and those guys [on the state supreme court] are over in [the capital], and by God, I'm deciding this case.'

Carter, supra note 73, at 232.

81 See DONALD BLACK, SOCTOLOGICAL JUSTICE 8-18 (1989) (concluding from a survey 
sufficiently free from rules to make those distinctions. Ethnographic studies of practicing lawyers find that attorneys rarely "[feel] constrained by rules, regulations, and procedures" 82 and "generally disparage[]...the rationality, importance, or efficacy of legal rules." 83 Local judges sometimes distrust supreme court rulings due to the justices' distance from daily trial practice. ${ }^{84}$ The procedural entitlements that norms supplant can seem excessive or superfluous in real-world trial settings. The norms themselves may seem legitimate precisely because they are revised by ground-level experience and are devised by professionals who naturally trust their own commitments to faimess.

\section{UNPACKING NORMS}

Some norms are fully in control of local practice groups (whose members, in turn, are restrained by them). More interestingly, other norms are responses to broad, systemic tensions that make the entitlement undermined by the norm impractical. The nature of norms can reveal whether local practice groups are the

of empirical research that law plays a lesser role among "social equals" than among socially disparate parties). The thesis accords with psychological research finding that ordinary citizens place great emphasis on the faimess of procedures in the absence of objective bases for judging the faimess of outcomes. See TOM R. TYLER, WHY PEOPLE OBEY THE LAW 109 (1990).

These faimess commitments help explain why lawyers less often choose to adopt norms than to ill-serve the interests of wealthy clients; norms there would seem less fair. See JOHN P. HENZ \& EDWARD O. LAUMANN, CHCAGO LAWYERS: THE SOCIAL STRUCTURE OF THE BAR 140 (1982) (discussing findings that 'Tawyers' values will be influenced by ... client[] interests"); Robert L. Nelson, Ideology, Practice, and Professional Autonomy: Social Values and Client Relationships in the Large Law Firm, 37 STAN. L. REv. 503, 511-28 (1985) (finding corporate lawyers' personal views converge over time with their clients' interests and values). Compare EVE SPANGLER, LAWYERS FOR HIRE: SALARIED PROFESSTONALS AT WORK 58 (1986) (reporting a corporate lawyer's fondness for his clients) with NARDULLIET AL., supra note 15, at 145 (documenting one jurisdiction with an "exceptionally conservative [criminal] defense bar," represented by one attomey who said, "I don't really identify with my criminal clients. ... I'm not from that level of society.").

82 Carrie Menkel-Meadow \& Robert G. Meadow, Resource Allocation in Legal Services: Individual Attorney Decisions in Work Priorities, 5 LAW \& POL'Y Q. 237, 250 (1983) (basing its findings on interviews of attomeys).

83 SARAT \& FELSTINER, supra note 29, at 96. Those findings stand in contrast to the assumption that lawyers largely legitimate prevailing arrangements in the legal system with uncritical views of its operation. See id. at 86. Nelson and Trubek's work suggests this conclusion is equally or more true for ethical rules. See Nelson \& Trubek, supra note 7, at 213; see also infra Part V.D.2 (discussing Nelson \& Trubek's work).

${ }^{84}$ See, e.g., Carter, supra note 73, at 232 (recording as representative one state trial judge's statement, "[t]here are cases where I say to myself, "Well, the precedent is on all fours, but I think it's wrong, and those guys [the supreme court] are over in [the capital], and by God, I'm deciding this case."'). 
source for change of dysfinctional norms, or whether norms are a sign that some rules are infeasible in the larger justice system and need to be revised. In the latter case, norms point the way to revising formal rules. What follows is a survey of several norms that illustrate the various types and causes of practice norms, yielding a taxonomy of norm types.

\section{A. Discovery Norms}

Consider again the norm against discovery motions and bills of particulars. ${ }^{85}$ Discovery practice was at issue in the Supreme Court's decision in Strickler $v$. Greene, 86 a capital case in which the defense attorney relied on the prosecution's open file policy in lieu of filing a discovery motion. A norm against discovery motions presents a problematic strategic choice for defense attorneys. If they forgo motions and comply with the norm, they may gain informal advantages for clients, such as fuller discovery of inculpatory evidence (to which there is no constitutional right) and an amicable working relationship that yields benefits like better plea bargain offers or time savings. ${ }^{87}$ In doing so, however, they may also sacrifice legal rights and strategic advantages for clients.

Without a discovery motion, defendants may have waived rights to object to discovery withheld by prosecutors, particularly items to which they have only a statutory, rather than constitutional, right. ${ }^{88}$ Moreover, failure to request discovery formally can affect even evidence prosecutors are required to disclose under Brady v. Maryland..$^{89}$ A specific request can affect the assessment of whether undisclosed evidence is "material" and whether a Brady violation occurred. Under an earlier standard set out in United States v. Agurs, 90 materiality was assessed under a two-tiered framework, so that nondisclosures of

85 See supra text accompanying note 27.

86527 U.S. 263 (1999). It should be noted that it is unclear whether the practice in Strickler was a norm (enforced by sanctions), a mere custom (for which the defense would have faced no penalty for filing a motion), or mere laziness.

87 Improved plea bargains as a result of cooperation must be weighed against the improved bargaining position one can achieve by demonstrating zealous preparation and obtaining discovery that might not otherwise become a factor in negotiations or trial.

${ }^{88}$ Many state criminal discovery rules give defendants much broader discovery rights than the Constitution requires. See, e.g., CAL. PENAL CODE $\S 1054.1$ (West Supp. 2000); ILL. S. CT. R. 412; N.Y. CRIM. PROC. LAW $\$ 240.20$ (McKinney 1999); OHIO R. CRIM. P. 16.

89373 U.S. 83, 87-88 (1963) (describing a due process obligation to reveal exculpatory evidence even without a defense request). But see Strickler v. Pruett, 149 F.3d 1170 (4th Cir. 1998), rev'd, Strickler v. Greene, 119 S. Ct. 1936 (1999) (requiring defense attomey, in order to avoid procedural default, to use "reasonable diligence" to discover Brady material); Stockton v. Murray, 41 F.3d 920, 925 (4th Cir. 1994) (same).

90427 U.S. 97 (1976). 
evidence that were specifically requested by the defense were treated more favorably to defendants than evidence for which there was no request or only a general, boilerplate request.91 The Supreme Court replaced that two-tiered structure in United States v. Bagley ${ }^{92}$ with a single standard, which defines evidence as material if there is a "reasonable probability" it would have affected the trial outcome. Nonetheless, the Court described the new approach as "sufficiently flexible" to distinguish between specific-request and no-request or general-request cases. ${ }^{93}$

Thus, even under Bagley, defendants lose a strategic advantage on Brady material by not filing specific discovery motions. Moreover, a significant minority of state supreme courts continue to employ an Agurs-style two-tiered approach under state law to ensure further protection for defendants filing specific requests. ${ }^{94}$ To the extent a norm encourages reliance on open file policies in lieu of discovery motions, it even jeopardizes a defendant's right (more specifically, her posttrial remedy) to evidence a prosecutor is required to disclose with such a motion.

The no-discovery-motions norm means attorneys can preserve those rights only at a cost. Norms designed to increase the efficiency of criminal litigation and save attorney and court resources undermine legal entitlements in a way that increases the risks (that is, of wrongly withheld discovery) against which the entitlement guards. It can also add a marginal incentive for abuse and decrease the checks on discovery violations; 95 prosecutors can gamble that evidence they

91 See id. at 111-12. Evidence specifically requested by the defense was deemed material if it "might have affected the outcome of the trial," while evidence for which there was only a general request or none at all was deemed material only if it "create[d] a reasonable doubt [about defendant's guilt] that did not otherwise exist." Id. at 104, 112.

92473 U.S. 667 (1985).

${ }^{93}$ See id. at 682-84 (reasoning in part that nondisclosure after a specific request not only deprives the defendant of evidence but also misleads him into thinking the evidence does not exist and therefore into abandoning investigative and trial efforts in that direction).

94 See, e.g., Roberts v. State, 881 P.2d 1, 7-8 (Nev. 1994); State v. Marshall, 586 A.2d 85, 91-92 (N.J. 1991); People v. Vilardi, 555 N.E.2d 915, 920 (N.Y. 1990); Commonwealth v. Gallarelli, 502 N.E.2d 516, 519 n.5 (Mass. 1987).

95 That is, a prosecutor who knows that the practice norm requires forfeiture of claims about discovery violations may try to take advantage of that forfeiture. That incentive likely is supported by a justice rationale: a prosecutor who feels sure a defendant is guilty may be more likely to with hold exculpatory evidence and view the choice as one that serves the correct final outcome. Cf. Resnik, supra note 35, at 413-14 (noting a similar problem with managerial judging in discovery contexts, in which judges "are restrained only by personal beliefs about [their] proper role" and some of their actions are "invisible[] and unreviewable"); Stephen J. Schulhofer, Criminal Justice Discretion as a Regulatory System, 17 J. LEGAL STUD. 43, 78-79 (1988) (noting that even in the best jurisdictions, criminal defense attorneys get only a fraction of the information through discovery that civil litigants routinely receive). 
withhold will be deemed after trial insufficient to "undermine confidence in the outcome."

The norm against formal discovery, like many others, also has subtle effects on the quality of routine practice. ${ }^{96} \mathrm{~A}$ key distinction between exceptional and mediocre lawyering is that an attorney works hard and imaginatively even with "ordinary" cases in search of winning (perhaps unusual) strategies. ${ }^{97}$ Zealous discovery practice holds prosecutors and courts to disclosure obligations that may go unfulfilled otherwise; it challenges customs of minimal discovery practice that are facilitated by trial court practices of using standing discovery orders for all cases and by lax appellate review standards that reduce prosecutors' risks of insufficient disclosure..$^{98}$ Bill Geimer has argued that zealous discovery practice can help expand the working definition of the kinds of evidence covered by the Brady obligation. 99 Moreover, careful discovery practice takes advantage of the gap between the disclosure obligation and the appellate review standard-Brady material might be useful to the defense

${ }^{96}$ Note how such a norm can interplay with well-documented concem of attorneys for their reputations. Attomeys build reputations in part by displaying good judgment in motions practice. See FLEMMING ET AL., supra note 16, at 164. Attomeys noted that those who file junk motions get all their motions dismissed; those who file only a few, good motions get them taken seriously. See id. at 168-71. Learning the guidelines set by this norm enhances their reputation (which may redound to the client's benefit). See id. If the attomey is known for good judgment, those motions she does file will be given more careful consideration. See id. at 164 70. Moreover, reputation becomes part of the information other players use to assess the merits of motions. See id. at 170-71. Without full knowledge of facts, which may require a hearing, and perhaps without thorough review of the law (depending on how well the judge or district attomey knows the law at issue), the assessment of a motion often is made on imperfect information. How imperfect it will be may vary; a prosecutor, for instance, may have considerable factual information available from her own file.

97 See Gabriel J. Chin \& Scott C. Wells, Can a Reasonable Doubt Have a Reasonable Price? Limitations on Attorneys' Fees in Criminal Cases, 41 B.C. L. REV. (forthcoming Dec. 1999 ) at 49, n.155 \& 59-60 (manuscript) (arguing "routine loser" cases can be won by zealous, imaginative advocates who do not treat them routinely, and noting that "[m]any United States Supreme Court cases have involved 'routine' misdemeanor convictions"' (citing cases)).

98 This describes the case law of the Fourth Circuit now at least partially overtumed by Strickler. See Strickler v. Pruett, 149 F.3d 1170 (4th Cir. 1998), rev'd, Strickler v. Greene, 119 S. Ct. 1936 (1999) (requiring defense attomey, in order to avoid procedural default of claim, to use "reasonable diligence" to discover Brady material that the state is constitutionally required to reveal); Stockton v. Murray, 41 F.3d 920, 925 (4th Cir. 1994) (same). My colleague Bill Geimer makes this point in CLE programs to criminal defense attomeys, particularly with respect to capital litigation. See William S. Geimer, Pretrial Kyles at 7-8 (Fall 1998) (unpublished manuscript for CLE program, on file with author). Professor Geimer also emphasized trial court use of standard-form discovery orders.

${ }^{99} C f$. Geimer, supra note 98 . Of course, there are time and resource costs to zealous practice, which partly explains some of the failure, though probably only part. 
pretrial but be deemed on appeal not to have been likely to alter the trial's outcome ${ }^{100}$-to force the disclosure of evidence when it is useful rather than merely to preserve an issue for appeal. ${ }^{101}$

Recognizing a discovery-norm effect argues for several responses from Brady doctrine. The case law already includes the first-a reliance doctrine that recognizes that defendants forgo discovery motions to take advantage of open file policies. Recognizing such reliance, as the Court did in Strickler, prevents a finding of procedural default. ${ }^{102}$ Additionally, the effects of norms call for a reassessment of related rules, such as one allowing prosecutors to condition plea bargain offers on the defense not pursuing discovery. ${ }^{103}$ Doctrines balance many competing concerns, and the final calculus may still support such a rule, but norms reveal its cost to be higher: the rule creates a means to enforce an undesirable norm. The norm also argues for a more stringent standard of view for Brady claims to minimize the dangers noted above-lax review of no-request Brady claims. Strickler can be read as a move in this direction. It signals to jurisdictions such as the Fourth Circuit that lower courts should not weaken Brady, particularly by findings of default arising from failures to file discovery motions. Finally, jurisdictions could encourage the use of formal motionsreducing the costs of forgoing them noted above-by minimizing prosecutors' obligations to respond to them with formal writings. If prosecutors can answer such motions with open file policies rather than with written responses, they have much less incentive to discourage such motions. ${ }^{104}$

Discovery, then, is an example of a practice area in which formal rules have

100 This was exactly the outcome in Strickler. Strickler, 119 S. Ct. at 1948.

101 See Geimer, supra note 98, at 2-3. Similarly, bills require prosecutors to specify grounds for criminal charges. They provide some limit on the way the state may prove allegations in court, see, e.g., OHIO R. CRIM. PRO. 7(e) (allowing an amendment of the indictment anytime before trial within the judge's discretion as "justice requires"); counter the practice of vague indictments that include little more than statutory elements; provide some information on the prosecution's case theory; and focus the defense attomey's investigation and case preparation. Employed as part of standard practice, bills should have a subtle but, over time, real effect of raising the quality of practice on both sides. A norm for a bill of particulars-or detailed discovery - should eventually become part of the baseline minimum of activities around which court budgets, attomey staffing levels, and individual lawyer time management are set.

102 The Supreme Court in Strickler built on existing doctrine and uncontroversially accepted that the defendant had relied on the prosecutor's open file policy in his decision not to file discovery motions. See Strickler, 119 S. Ct. at 1949.

103 See generally State v. LaForest, 665 A.2d 1083 (N.H. 1995) (holding that it is not a due process violation for a prosecutor to condition a plea bargain offer on defendant's agreement not to pursue further discovery, including the results of a "rape kit" medical exam in a rape case).

104 See HEUMANN, supra note 16, at 61-69, 107. 
in part accommodated the norm, and in other respects could easily adapt to both discourage the norm and to reduce its undesirable consequences. Such accommodation serves the underlying policy goal of Brady and discovery generally. Brady exists because trust of prosecutors to reveal exculpatory evidence, even with clear ethical obligations, ${ }^{105}$ is an insufficient safeguard. Norms ideally arise in contexts of trust and ongoing cooperation. To the extent a norm is a mutually designed practice among equal opponents (rather than one imposed by a powerful side, such as prosecutors), trust should minimize abuse. ${ }^{106}$ Yet unequal influence between the opposing sides reduces confidence that this discovery norm is an adequate substitute for legal rights. ${ }^{107}$ Rule changes can modestly discourage the norm and its attendant costs while also capturing some of its benefits.

\section{B. The Closing Argument-Objection Norm}

Another rule that conflicts with a practice norm in some jurisdictions relates to closing argument. Often, case law requires that defense objections to improper comments in the prosecution's closing argument must be made immediately at the time of the comment, rather than at the end of the argument, to avoid waiver of the objection. ${ }^{108}$ Yet in some jurisdictions, particularly rural ones (the sorts of smaller communities in which norms readily arise), there exists a strong norm of courtesy and collegiality that counsels against interrupting an adversary's closing argument. ${ }^{109}$ (That norm accords with the strategic judgment of trial attorneys

105 See MODEl Rules OF PROFEsSIONAL CONDUCT Rule 3.8(d) (1997); MODEL CODE OF PROFESSIONAL RESPONSBIIITY DR 7-103(B) (1980).

${ }^{106}$ In economic terms, group members cooperate to create a norm in order to reap a collective good-time and effort savings from forgoing written motions, responses, and hearing. That cooperation comes at a cost, particularly in this instance for defendants, who risk losing appellate remedies. Failure to disclose evidence pursuant to the Brady obligation and the norm that substitutes for a specific request represents a defection from the group's norm agreement; the prosecutor reaps the collective good without paying a cost, i.e., fulfilling the obligation to disclose. Occasions in which defection is more likely, especially when defection cannot be easily monitored or punished, provide stronger basis for court intervention. See Eric A. Posner, The Regulation of Groups: The Influence of Legal and Nonlegal Sanctions on Collective Action, 63 U. CH. L. REV. 133, 155-61 (1996).

${ }^{107}$ For further discussion of agency problems, see infra Part V.D.1.

108 See Commonwealth v. Beavers, 427 S.E.2d 411, 419 (Va. 1993); Commonwealth v. Cheng, 393 S.E.2d 599, 605-06 (Va. 1990); see also Mack v. Commonwealth, 454 S.E.2d 750 (Va. App. 1995).

109 My colleague, Bill Geimer, a leading authority and practitioner in Virginia criminal trial practice, regularly wams attomeys in CLE settings about the cost, in light of strict waiver doctrine, of following "Virginia's long tradition of civility" by not objecting during an 
who disfavor making objections during closing for fear of alienating juries.) The norm is interesting as a cultural modification of the adversary system; adherents have little to gain beyond amicable work relations with repeat opponents or judges and a corresponding courtesy during their own arguments. Yet their clients may lose the entitlement barring prejudicial comments under a rule requiring immediate objection.

Here again is a norm to which the formal rule could easily adapt. The rationale for the rule rests largely on the need for the judge to be able to correct improper statements with a jury instruction, rather than be left with only the remedy of mistrial for objections raised after trial. Yet a modified rule allowing counsel to make objections at the end of an opponent's argument still leaves time to instruct the jury before it retires. (It also gives counsel a few moments to formulate the bases for objections, which may not always come to mind at the moment of the offending comment.) In addition to preserving courteous relations among counsel and reducing interruptions during trial, such a rule reduces the number of uncorrected rule violations. Beyond a defendant's personal interest, the justice system itself values adjudications resolved without the taint of prejudicial arguments. In those many jurisdictions that lack such a courtesy norm and where zealous advocacy prevails, no rule change is needed; but, in areas where the norm has proved resistant to the incentive effect of the rule, case law can easily adapt to the practice in service of both the defendant's and the public's interests.

\section{Norms Regarding Trials and Expert-Witness Funds}

In contrast to the preceding examples, two other widely observed norms directly implicate the resources of the justice system as well as the work loads of attorneys. Recall the example of the Ake motion for an expert witness in a misdemeanor case. A utilitarian explanation of a practice norm discouraging such motions emphasizes a judge's wish to conserve limited court funds by discouraging requests for Ake funds. She may also want to conserve time and effort by not hearing such motions, especially if, in the context of the case, their value seems marginal (and they raise the odds of an appealable issue). ${ }^{110}$ Funds

opponent's argument, which he observes even in his area of special expertise, capital trials. Interview with William S. Geimer, Professor of Law, Washington and Lee University (Spring 1999).

110 One judge, who chaired a committee appointed by Chief Justice Rehnquist to view the process of appointing federal defenders, acknowledged the temptation of judges to retaliate against lawyers who increase their work load with aggressive advocacy. Frankel, supra note 41 , at 68. He argued for his committee's recommendation that judges have less control over those appointments, which they can use to weed out aggressive defenders, by noting that judges are tempted not to re-appoint a defender who is "really very aggressive, filing all the 
that the court dispenses come from a budget that judges do not control. Judges are acutely aware of mismatches between the cost of entitlements created by appellate decisions and legislative decisions to fund them. Just because a court says a defendant is entitled to an expert does not mean the legislature has allocated funds for every defendant. The expert-funds norm regulates those limited resources.

The same is true with regard to jury trials. Several studies document a widely held view among judges that some criminal cases are not "worthy" of trial, that trial demands in certain cases are "unreasonable," independent of the court's time constraints or docket backlog. ${ }^{111}$ In Heumann's sudy, Connecticut judges explicitly admitted use of a "trial penalty" for insisting on a trial (or other use of court resources, such as motion hearings) viewed by judges and others as unnecessary. The judges' comments document a substantive norm that redefines the formal right to trial. A defendant "deserves to be penalized for the trial because he takes up the court's time, there is expense involved, and so on.... He's got a right to try a case where he has got a reasonable position."112 A large multistate study finds the same view elsewhere; 113 it is also documented in a Florida trial court. ${ }^{114}$

The Supreme Court has read the Sixth Amendment to give a jury trial right to every defendant, in state or federal court, facing the possibility of at least six

motions, making twice as much work for the judge."Id.

111 See FLEMMING ET AL., supra note 16, at 56-75; HEUMANN, supra note 16, at 140-43. The sanction also accords with my own perceptions in practice as a public defender in two states.

112 HEUMANN, supra note 16, at 143. One would expect to see this same sort of normbased modification of entitlements in civil contexts. Consider, for example, a tenant or debtor who insists upon a jury trial in an eviction proceeding brought by a landlord or creditor.

113 See FLEMMING ET AL., supra note 16, at 110,118-19 (recounting judges in other jurisdictions referring to "unnecessary" or "illegitimate" trials); $c f$. Resnik, supra note 35 , at 402 (suggesting that federal judges in civil cases coerce settlements by implying "the judge would take a dim, and possibly hostile, view of either side's insistence on going to trial").

${ }^{114}$ See In re Inquiry Concerning Judge Damron, 487 So. 2d 1, 3 (Fla. 1985). In this case, a judge was removed from office for, among other things, the following on-the-record colloquy with a defendant who was before the judge for violating probation by failing to pay a fine: "DEFENDANT: Would there be any time involved in this once everything is paid off?" $I d$. at 3. "JUDGE DAMRON: If you want to go to a jury trial for not paying your fine, it would be. The taxpayers won't pay for something that's so foolish." Id. In a separate case, the judge "told [a party] she would receive the maximum sentence upon conviction if she persisted in her plea of not guilty." Id. Judge Damron also threatened punishment for insisting on the right to counsel. "JUDGE DAMRON:... You can have an attorney if you want, and that way I can give you two years. You want me to get you a public defender? DEFENDANT: No, sir. JUDGE DAMRON: I didn't think you did. ..."Id. at 2. 
months in jail. ${ }^{115}$ Legislatures, however, have not funded courts (plus prosecutors and defenders) sufficiently to provide jury trials for even a substantial minority of cases. ${ }^{116}$ Not every defendant wants a trial, and many factors go into decisions whether to plead guilty or to stand trial; 117 judicial (and attorney) pressure on parties, driven by funding limits, is surely a major factor. In response to incompatible decisions from competing institutions, trial-level professionals evolve norms to mediate the conflict. The norm sub silentio rewrites the formal legal rule but in accord with implicit legislative preferences. ${ }^{118}$ Radical as the notion is in light of prevailing doctrine, the norm could be a sensible regime for severely limited trial resources: if trials can be handled for only a small portion of cases, judges and lawyers should prescreen them and reserve juries for certain close factual or legal issues.

Such norms should signal to appellate courts that doctrines may be unworkable and need to be re-evaluated, at least to the extent that resources motivate the norm. Norms driven by such tensions are disturbing only in the sense of the canary in the coal mine: they identify a problem in need of response. The Supreme Court's decisions extending the jury trial right have prompted no real increase in the use of juries. The values that drove those decisions have been implicitly rejected by other policymakers, particularly legislators.

It is likely that, with some jury trial resources diverted to minor misdemeanors, fewer felonies are tried by jury than otherwise. Jury doctrine may have diverted policymakers from choosing a more feasible regime to serve some of the same goals. If lay participation in criminal adjudication is the underlying goal, it may be preferable to try more felonies by jury and resolve misdemeanor cases with a form of lay magistrates rather than juries, which has long been the English practice. ${ }^{119}$ The Supreme Court's cases concerning the right to a jury

115 See Blanton v. City of North Las Vegas, 489 U.S. 538, 541-42 (1989); Baldwin v. New York, 399 U.S. 66 (1970).

116 See generally Stephen J. Schulhofer, Is Plea Bargaining Inevitable?, 97 HARV. L. REv. 1037 (1984) (concluding from empirical studies that about one quarter of felony defendants would want to plead guilty even without inducements, and that $75 \%$ of felony cases could be resolved by bench trials with only small increases in judicial resources).

117 The literature on plea bargaining is voluminous. One recent historical study attributes early development of the practice to the need in the 1830 s and 1840 s to strengthen local government, social order, and political stability. See Mary E. Vogel, The Social Origins of Plea Bargaining: Conflict and the Law in the Process of State Formation, 1830-1860, 33 L. \& SOC'Y REV. 161 (1999).

118 Note the implications that this raises for judicial constitutional interpretation as an anti-majoritarian check, a topic beyond the scope of this paper.

119 Bill Pizzi, in his recent book criticizing America's criminal trial process, endorses the lay magistrate approach. See WILLIAM T. PIZZ, TRIALS WITHOUT TRUTH 105-06, 224-27 (1999). 
prevent jurisdictions from experimenting with such alternatives. While they can offer lay magistrate adjudication, they cannot remove the misdemeanor jury trial right without reducing sentences; they can discourage misdemeanor juries only by subterfuge like the trial-penalty norm.

Similarly, the expert-funds norm may have achieved a policy preferable to the extension of Ake to all criminal cases. If the public policy, reflected in legislative funding levels, is not to provide useful experts in every criminal case, then rationing funds to reserve them solely for serious cases is sensible. If experts provide fact finders with useful information, they should increase the accuracy of judgments and reduce erroneous convictions. ${ }^{120}$ Rationing expert funds by the type of case-more funds for felonies, less for misdemeanors-should lead to differential error rates. One may justifiably aim for a lower error rate for felonies than for misdemeanors, in which the stakes are lower.121 Some state jurisdictions, in their interpretations of $A k e$, have limited the entitlement to felonies. ${ }^{122}$ Others have not, ${ }^{123}$ and in those we should expect the local level expert-funds norm to be common. ${ }^{124}$ Although it achieves much the same end as doctrinal revision, the norm does so in a less desirable way, denies in practice what the law offers in public, and makes policy in an institutional setting less public and trustworthy than court and legislative decisions. In such contexts, norms that revise legal rules are signals that courts themselves need to revisit rules. ${ }^{125}$

${ }^{120}$ I am holding aside disputes about experts who cause more confusion than clarity and whose testimony is more partisan bias than fact. I depend on the limited contention that at least a subset of experts provide useful information and views that improve fact-finding compared to a process without expert testimony.

121 The same rationale would support a norm discouraging appeals in misdemeanor cases and reserving those resources for more serious convictions - but that calculus may not hold if the value of the appeal is clarification of an important rule (many Supreme Court cases arose from misdemeanors) rather than the defendant's conviction and sentence.

122 See, e.g., Husske v. Commonwealth, 448 S.E.2d 331 (Va. App. 1994).

123 See, e.g., Elmore v. State, 968 S.W.2d 462 (Tex. App. 1998); Ventura v. State, 801 S.W.2d 225 (Tex. App. 1990).

124 In Elmore, the Texas Court of Appeals held that Ake funds could be available to defendants charged with misdemeanor DUI on appropriate facts and noted the economic burden this could put on local governments, which it cautioned should not outweigh an individual's right to fair adjudication. See Elmore, 968 S.W.2d at 466.

125 A recent decision reiterating state case law that some trial courts had resisted might be another example of trial courts signaling that a formal rule is impractical or of little value in practice. In Gwartz v. Superior Court, 71 Cal. App. 4th 480, 481 (Cal. Ct. App. 1999), the court reprimanded judges "on the local superior court bench" who refused parties an opportunity for oral argument on summary judgment motions despite what the appellate court here describes as clear case law mandating oral argument. While the argument rule serves public and party interests in procedures that aid at least the appearance of due process (which 
This analysis emphasizes resource constraints. However, implicit in both norms are rationales of distributive justice, which help explain judges' normative view of their actions and which ease the norms' conflict with party entitlement and judges' professional obligations. For the expert-funds norm, the rationale may work like this: only wealthy litigants can afford to pay for experts in such cases; most middle-class litigants cannot. ${ }^{126}$ Ake, fully implemented by zealous defense counsel, would therefore effectively give indigent litigants more justice-a larger entitlement that improves outcome accuracy-than working people would get. This is unfair. Thus, real justice requires restricting $A k e$ funds, perhaps only to clear cases where even middle-class people would purchase an expert. Faimess requires a sanction to discourage Ake motions by indigent defendants who insist on more entitlements than others receive.

The same sort of rationale supports the trial-penalty norm. This norm implies judgments about entitlements to procedural justice ("cases without conflicting factual evidence are not entitled to trial") and distributive justice ("those who admit guilt deserve more favorable treatment than those who do not'). Note the norm rations trial resources by reserving trials for cases with close factual or legal questions. ${ }^{127}$ It represses other public process values and a

trial judges might undervalue), the trial judges' resistance may indicate that argument is of little real use to courts' decisionmaking, especially in light of docket constraints those courts face. Like a rule mandating jury trials in all cases, the rule here may not work well in all cases and court contexts, and the judges' resistance, like a norm, may signal that problem.

126 Economists presumably would point out that many middle-class parties could find the funds-several hundred dollars or more-to pay for an expert, but would conclude the cost not worth the relatively small $e x$ ante chance that the expert's analysis and testimony would favorably affect the outcome of the case. Thus, they choose not to have an expert rather than be denied one due to their limited means.

127 In as much as it revises the trial right in this way, the norm is analogous to lay "commonsense justice" views that conflict with legal rules and affect jury decisions. See generally FINKEI, supra note 72 (discussing studies that indicate jury decisions are affected by lay standards of intuitive justice), and that inform other "nullification" acts by judges and prosecutors; see also MORTIMER KADISH \& SANFORD KADISH, DISCRETION TO DISOBEY 4566, 80-85 (1973); Simon, supra note 73, at 1116-17 (describing discretionary prosecution decisions as "routine" nullification). Arguably, the norm revision of substantive law is less legitimate than analogous jury action. At least the jury is a democratic, deliberative body with a mandate specified in case law to temper law application with community justice sentiments. See, e.g., Taylor v. Louisiana, 419 U.S. 522, 530 (1975) (stating that the jury should bring to its verdict "the commonsense judgment of the community"); Peters v. Kiff, 407 U.S. 493, 503 (1972). The norm, in contrast, is largely a product of the professional actors against whose bias the case law designs such protections as the jury trial. See Taylor, 419 U.S. at 530 (explaining the jury is "a hedge against the overzealous or mistaken prosecutor"); Johnson v. Louisiana, 406 U.S. 356, 373 (1972) (stating that the jury checks the risk of a "compliant, biased, or eccentric judge"). 
party's subjective preference for trial over settlement. ${ }^{128}$

Infusing norms with justice notions-to view them as right, even when they contradict a formal rule-reduces the cognitive dissonance of professionals who are compelled by resources to ration entitlements. However, it also helps drive norms to undercut rules beyond what material constraints and policy conflicts require. In a telling study of two similar counties in the same state, David Lynch found one had a substantially higher rate of jury trials than the other, a difference that could not be attributed to funding or any other factor beyond local custom and preferences of judges and (some) attorneys. Both jurisdictions disposed of fewer than half of the cases by jury trial. Part of the need for nontrial dispositions is surely limited budgets, but only part. The study suggests that the difference in the two counties' trial rates was attributable to norms not dictated by resource constraints. Lynch describes judges using several sanctions to enforce personal trial-rate preferences. Other studies confirm that finding in other jurisdictions. ${ }^{129}$ Even with norms driven in large part by resource pressures, then, justice notions and self-serving personal preferences have an independent effect. ${ }^{130}$

This effect is unfortumate. The trial-penalty norm alters the behavior of every player in the system. Judges alter sentencing decisions to enforce it. Prosecutors increase sentencing recommendations after trial in accord with the norm. Defense attorneys will change their strategic thinking and client advice in light of it; they may pressure clients to plea in "unreasonable" cases, independent of the risk of a penalty or even the attorney's self-interest with respect to fees for court appointments. ${ }^{131}$ Clients (especially those who are risk averse), when informed

128 See Geimer, supra note 98, at 10-11 tbl. (citing Fourth, Fifth, and other Circuir Court cases as well as state court cases from Virginia, Tennessee, North Carolina, Georgia, Florida, and Alabama).

129 See Lynch, supra note 20. For other studies, see, for example, Schulhofer, supra note 116 (concluding from empirical studies that about one quarter of felony defendants would want to plead guilty even without inducements, and that $75 \%$ of felony cases could be resolved by bench trials with only small increases in judicial resources); $c f$. Teresa White Cans \& John A. Kruse, Alaska's Ban on Plea Bargaining Reevaluated, 75 JUDICATURE 310, 317 (1992) (describing widely different rates of plea bargaining between Fairbanks and Anchorage, Alaska, and attributing the difference largely to the chief prosecutors' differing views on the desirability of bargains rather than on resource constraints).

130 This observation is consistent with research on organizational theory and institutionalism, which describes perceptions within institutional environments that some practices are compelled by necessity, such as resource limits, when in fact they are contingent institutional choices. See generally DiMaggio \& Powell, supra note 57.

131 In some jurisdictions, it is surely the unreasonably low cap on fees for trials that encourages attomeys to urge guilty pleas. However, this is not always the case and does not mean the norm cannot have an independent effect. One state court judge has observed with dismay the widespread use of pleas in his jurisdiction, despite a seemingly generous fee scale that should encourage counsel to recommend trials to criminal defendants. See E-mail from 
of the norm, will change preferences as well. It adds the strong weight of private normative views to the public criteria on which sentencing policy is based. In addition to considerations of retribution, moral blame, or deterrence, for instance, judges' sentencing decisions-and prosecutors' recommendations-will be driven by the trial-penalty norm. ${ }^{132}$ The expert-funds norm similarly affects every player's decisions and undermines the public purposes of the doctrine, and the same risk exists for the public values protected by other rules. ${ }^{133}$ It is disturbing that local practice groups devise norms that undermine formal rules. Doctrinal revision can reduce that behavior to the extent resources dictate it. To the extent norms are a function of self-interested action mixed with ideological commitments, however, the problem is a failure of professionalism and the remedy is more complicated.

\section{Collegial Fair-Dealing Norm}

In contrast to the discovery norm, which aims to achieve informally much of what formal rules achieve, and the trial-penalty norm, which in part responds to material pressures stemming from conflicts between courts and legislatures, what this Article calls the fair-dealing norm illustrates a norm driven entirely by private justice standards. A vivid example comes from a county study in which a defense lawyer freely described a fair-dealing norm among opposing attorneys that included an obligation not to "take advantage" of an opposing prosecutor, even if the norm behavior injured his client.

"There have been many cases where a D.A. has made a deal with me and I look at him and I say, 'Hey, that's not enough. You're too low on the case.' The guy says he wants a $\$ 250$ fine. I say, 'No, make him pay $\$ 500$.' Because it's fair." 134

This example is one of several such instances found in the study in which

Hon. Steven Russell, Texas State Court Judge, to Crimprof listserve (July 31, 1998) (noting a county in which defense counsel usually plea for clients the day of appointment, despite a fee of $\$ 75$ per guilty plea compared to $\$ 250-500$ per day or partial day in court for trials).

132 See BAUM, supra note 46, at 85-87 (discussing the issue of whether judges sentence on legitimate or illegitimate criteria). For a brief survey of theories of sentencing policy, see RICHARD G. GARDNER \& MARTIN R. SINGER, CRIMES AND PUNISHMENT: CASES, MATERIALS, AND READINGS N CRIMINAL LAW 31-124 (2d ed. 1996).

133 A norm against challenges to nondiverse juries, for example, neglects the public cost of adjudication with unrepresentative juries, which include public perceptions of an illegitimate justice system, risk of inaccurate fact-finding, and a reduced check on prosecutors. See, e.g., Taylor v. Louisiana, 419 U.S. 522, 530 (1975); Peters v. Kiff, 407 U.S. 493, 503 (1972).

134 NARDULLI ET AI., supra note 15, at 135; see also FLEMIMING ET AL., supra note 16, at 141; 
attorneys followed the fair-dealing norm to a client's detriment. ${ }^{135}$ David Engel documents comparable conduct in a rural county's tort practice. "A lot of people are more conducive to settlement here just because they're attempting to be fair," one attorney explained. Yet the attorney confirmed Engel's broader finding that tort settlements generally were for medical expenses only, without compensation for other damages such as pain and suffering, despite the strength of such claims. ${ }^{136}$ (Indeed, it seems that the merit of such claims often went unknown; Engel found "discovery after the filing of a lawsuit was almost never used" in the county. ${ }^{137}$ Engel found that attorneys endorsed such faimess attitudes implicitly by letting such norms guide their practice decisions; one judge described it as a sign of local lawyers' "maturity."138

This sort of norm is telling in several respects. The norm clearly contradicts the attorney's duty of zealous advocacy and obligation to serve her client's interests. ${ }^{139}$ It reveals the attorney's relative independence from her client and the client's inability to monitor her agent. (One would not expect this norm to be strong in white-collar crime or corporate practices. ${ }^{140}$ It would be unlikely even in comparable county criminal court systems that had less collegial relations.) $)^{141}$ More significantly, this fair-dealing norm reveals the power of private justice standards (shared among professionals), which justify a norm that strongly contradicts formal professional obligations and yet serves no utilitarian function

135 The same attomey justified his refusal to "judge-shop" for forums that might favor his client with similar emphasis on maintaining credibility with other attorneys and the court. See NARDULLI ET AL., supra note 15, at 135; see also FlEMMING ET AL., supra note 16, at 141. One defense attomey said, "[t]here are times when you gotta go in and tell the judge, 'Don't give my guy probation. He's gonna screw up."' Another described strategy of allocating his professional effort among various clients: "[w]hat I do is I save the nol proses [dismissal requests] for the cases I think really deserve it. And the probations for the cases I think deserve it. On the other cases, it's '[d]on't do the crime if you can't do the time."' Id. (emphasis added).

136 See David M. Engel, Cases, Conflict and Accommodation: Patterns of Legal Interaction in an American Community, 1983 AM. B. FOUND. RES. J. 803, 854.

137 Id. at 854-55.

138 Id. at 854.

139 See MODEL CODE OF PROFESSIONAL RESPONSIBIITY Canon 7, E.C. 7.1 (1980), and MODEL RULES OF PROFESSIONAL CONDUCT Rules 1.2, 1.3 (1997).

$140 \mathrm{Cf}$. Nelson, supra note 81 , at 511-28. Nelson found that corporate aftomeys' views of their practice area over time converge with their clients' positions, such that specialization in this practice context shapes attomey valuations of legal issues. That sort of convergence, of course, reduces the agency problems that yield such effects as the examples of a fair-dealing norm discussed here.

141 See, e.g., NARDULLI ET AL., supra note 15, at 134 (describing the practice in DuPage County, Illinois, criminal courts as more adversarial, with much weaker collegiality among opponents, due largely to a prosecutor uninterested in cooperative relations). 
such as resource rationing.

The fair-dealing norm drastically reconceives professional roles, especially for the criminal defense attomey, from a partisan advocate serving the client's subjective interests to a more neutral professional helping to mediate a version of objective fairness. It shows a shift from adversarial processes of case resolution to one of collegial cooperation among relative elites. Thus, it contains the risks of shifting decisions from public processes to private ones. To the extent tort lawyers refuse to seek pain and suffering damages, for example, it undermines doctrines or statutes that authorize those damages for such cases in addition to disserving their clients. Criminal lawyers deny their clients zealous counsel (if not minimally effective counsel) and thereby undermine the process of adversarial adjudication among competent opponents that helps legitimate the criminal process. ${ }^{142}$ In this instance, however, while the norm undermines public values, courts and legislatures have no easy way to respond to the norm with rule revision. ${ }^{143}$ The response, if there is one, must come from professionalism rules, malpractice actions, and local attorneys themselves.

\section{E. Ambiguity of Norms}

How attorneys should respond to norms sometimes is unclear due to the variety of norms and their effects. Some norms that discourage resort to formal procedures and substantive entitlements are normatively acceptable. Consider norms, revealed in Heumann's description of young criminal attorneys, that discourage pretrial motions. Heumann finds that new attorneys who frequently seek trials and file all plausible motions incur informal sanctions that eventually chill their zeal for full procedural litigation. On the other hand, in what at first seems a contradiction, new defense attomeys learn that if they pursue plausible motions (or merely indicate their plan to do so), they receive a form of reward. To avoid litigating the motion, prosecutors will sweeten a plea bargain offer. Similarly, as the defense approaches a trial date without accepting a plea offer, the prosecutor may reward that determination with an improved offer. Heumann explains these apparently mixed signals by observing that prosecutors and judges distinguish between what they deem frivolous and meritorious motions. ${ }^{144}$ That

142 See Strickland v. Washington, 466 U.S. 668, 688 (1984) (discussing "the law's presumption that [defense] counsel will fulfil the role in the adversary process" and thereby "render the trial a reliable adversarial testing process").

143 This assumes, as the Supreme Court has made clear, that the judicial standard for ineffective assistance of counsel will not change dramatically to scrutinize defense counsel much more rigorously. See id. at 688 (stating that the "measure of attomey performance remains simply reasonableness" that does not undermine trial outcome).

144 See HEUMANN, supra note 16 , at 74. 
is, they reward strong motions and sanction frivolous ones.

If the work group's consensus is normatively acceptable-driven by good faith merits assessment rather than by the desire to avoid work or to chill attorney zeal-then this norm teaches good judgment. The attomey learns to assess motions carefully before raising them and to forgo marginal motions. She learns, in effect, to make trade offs (as legal rules do at a broader policy level) between faimess and efficiency. The norm thereby implies a conception of the attorney's role (further addressed in the next section) as a professional who rightly weighs interests beyond her client's. ${ }^{145}$ The attomey makes strategic judgments in light of public resource constraints as well as her client's interests. ${ }^{146}$

In more ambiguous instances, whether a norm is good or bad, whether it justifiably burdens a client's claims for public values or merely serves professionals' self-interest and private justice views, will depend on contextual examination. Some norms serve client interests partially and indirectly. An attorney may observe a norm of settlement to preserve good relations with a judge or opposing counsel in future cases. The present client may get a lesser outcome than she would through more zealous litigation, but the client also benefits from the relationship her attorney maintains by observing norms here and in previous cases. While she suffers a cost from the norm in this case, she may reap some benefit from the attorney's general adherence to it. ${ }^{147}$ The balance can be difficult to calculate in any given case.

Nonetheless, from the sample examined below, practice norms can be mapped along a continuum with resource constraints as the motivating cause at one end and self-dealing and ideological motivations at the other. This rough taxonomy clarifies the signals that one should take from norms and, as discussed in the final Part, identifies which players can respond to norms.

145 I assume here that attomeys filed at least marginal motions in their client's interest.

146 For an influential discussion of attomeys' duties to consider interests beyond the client's, see generally Simon, supra note 73. I discuss Simon's arguments infra Part IV.B.

147 If an attomey forgoes zealous advocacy for a client to preserve relations with judges and opponents, the present client's interests are to some degree sacrificed so that the attomey can be more effective for furture clients. That detriment might be offiset, however, by the gains this client reaps from the attorney's adherence to cooperative norms with prior clients. Cf. Marc Galanter, Why the "Haves" Come Out Ahead: Speculations on the Limits of Legal Change, 9 L. \& SOC'Y REV. 95, 117 (1974) ("[T] he demands of routine and orderly handling of a whole series of [one-shot clients] may constrain the lawyer from maximizing advantage for any individual ...."'). 
Table - Motivating Causes of Practice Norms

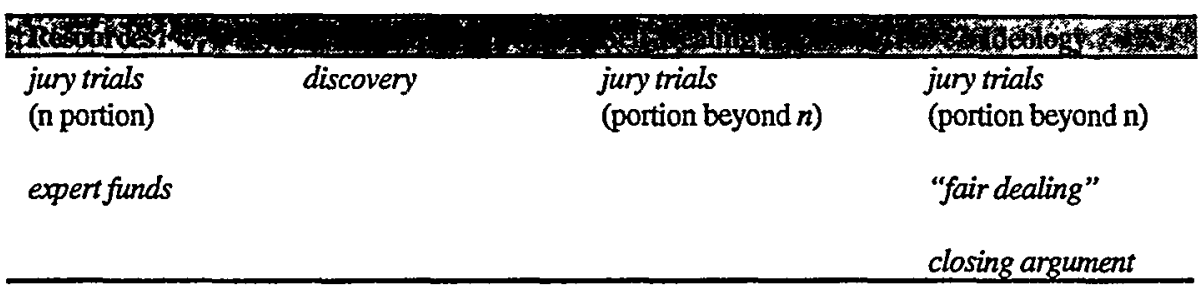

Note that the trial norm appears at both ends of the continuum because, while some large portion trial restrictions $(n)$ are due to resource constraints, some jurisdictions further restrict trials solely in accord with self-interest (e.g., reduced workload) or ideological motivations. The discovery norm lies midway on the continuum because its causes are mixed.

Norms on the left side are fairly legitimate responses to conditions that arise from political choices of appellate courts' institutional competitors, the legislative and executive branches. Holding aside arguments that challenge the legitimacy of legislative judgments (from public choice concerns about legislative self-dealing and political theory debates about majoritarian dominance of minorities), these trial-level norms should prompt appellate courts to reevaluate doctrines that reflect the considered judgment of professionals responding to conflicting public mandates. Even if they want to, local players can do little to change these norms. Those on the right side, in contrast, are fully in control of local lawyers and judges, and their weak legitimacy claims argue for their revision. In addition, both sorts of norms can mislead attorneys from the commitments of their professional role and ill-serve the public and client, whose interests lawyers must safeguard. 148 The next Part explores some of those detrimental effects.

\section{ASSESSING EFFECTS OF PRACTICE NORMS}

\section{A. Devaluation of Parties' Subjective Preferences}

The literature on legal ethics and the attomey-client relationship divides in large part on the priority accorded to client autonomy and the attorney's ability to act on considerations other than client interests. The question is how fully the attorney is obligated to facilitate and abide by the client's preferences rather than mediate that obligation with personal morals and societal or legal interests. In

148 See Menkel-Meadow \& Meadow, supra note 82, at 245 (discussing the significant effects that role conceptions can have on attomeys and reviewing similar literature); Sunstein, supra note 70, at 940 (arguing "[c]hoices are pervasively a function of social role"); $c f$. BAUM, supra note 46, at 85 (discussing "evidence that [judges'] role conceptions make a difference for judging"). 
other words, is the attorney solely an amoral agent for the client's wishes, or does the attorney balance the agency duty with public, professional, or third-party obligations?

It is obvious by this point that practice norms compromise client autonomy and lead the lawyer to mediate client interests with other interests. Practice norms often lead attorneys to discount or misperceive parties' subjective valuations of their disputes and their preferences about the options and processes used to resolve them. ${ }^{149}$ This effect of practice norms conflicts with a prominent conception of the lawyer's role that is the basis for legal education's leading approach to client relations, client-centered counseling, ${ }^{150}$ and with related approaches to legal ethics that give priority to client autonomy and conceive of lawyers largely as amoral agents bound by their clients' interests and preferences. ${ }^{151}$

Professionals tend to assume and impose objective preferences for litigating parties; norms further that tendency. ${ }^{152}$ Different clients may want to litigate

149 While skewed to the interests of lawyers and judges, norms can still be said to serve objective social welfare through such goals as conserving court resources and resolving disputed factual questions. See ELLICKSON, supra note 11, at 170-72. Microeconomics accepts the inability to compare interpersonal utility. See, e.g., JAMES COLEMAN, FOUNDATIONS OF SOCIAL THEORY 769-72 (1989); ROBERT COOTER \& THOMAS ULEN, LAW AND ECONOMICS 23 (1997); Michael Hechter \& Satoshi Kanazawa, Sociological Rational Choice Theory, 23 ANN. REV. SOC. 191, 194-95, 208 (1997) (discussing the same problem with respect to rational choice theory).

150 The leading text on client-centered counseling, and the dominant text in law school client counseling courses for two decades, is Lawyers as Counselors. See BINDERET AL., supra note 2; see also Robert D. Dinerstein, Clinical Texts and Contexts, 39 UCLA L. REV. 697, 700 (1992) (book review) (describing "the tremendous influence on clinical law teachers" of the Binder book).

151 For examples, see MONROE H. FREEDMAN, UNDERSTANDING LAWYERS' ETHICS 57 (1990); Stephen L. Pepper, The Lawyer's Amoral Ethical Role: A Defense, A Problem, and Some Possibilities, 1986 AM. B. FOUND. RES. J. 613, 614.

152 Cf. BINDER ET AL., supra note 2, at 17-18 (describing lawyers' "traditional view" of client problems and the "traditional approach" to solutions as involving "minimal client input"); Robert D. Dinerstein, Client-Centered Counseling: Reappraisal and Refinement, 32 ARIZ. L. REV. 501, 579 (1990) (noting that lawyers "tend to define client problems into particular categories" which leads lawyers to call "for relatively straightforward solutions," a practice that may "reflect a fundamental lack of sympathy for the client's perspective"); William L. F. Felstiner et al., The Emergence and Transformation of Disputes: Naming, Blaming, Claiming ..., 15 L. \& SOC'Y REV. 631, 645 (1980-1981) ("There is evidence that lawyers often shape disputes to fit their own interests rather than those of their clients."). For an argument that lawyers should put high priority on clients' subjective preferences for litigation goals apart from the case's objective value, see generally Dennis P. Stolle et al., Integrating Preventive Law and Therapeutic Jurisprudence: A Law and Psychology Based Approach to Lawyering, 34 CAL. W. L. REV. 15 (1997). 
similar claims very differently; comparable claims arise in different contexts and implicate different nonlegal consequences. ${ }^{153}$ Just as market prices are in fact only objective approximations of the subjective value of goods to any given contracting party, 154 the objective value of a legal claim-the money damages in a civil action, or restitution and punishment at issue in a criminal action-are only second-best approximations of a claim's subjective value to a client. Many legal disputes, and the processes used to resolve them, ${ }^{155}$ have significant personal or emotional value to disputants. ${ }^{156} \mathrm{~A}$ legal strategy motivated by concern for a party's subjective preferences with regard both to outcomes and procedure will often be different from one focused on a rational maximization of

153 See BINDER ET AL., supra note 2, at 3; id. at 5-15 (describing how nonlegal concerns can change client preferences on legal strategies and options); $c f$. Pildes, supra note 55, at 937, 955-59 (discussing how citizen preferences, with respect to goods regulated by public policy, vary with context and cultural values).

154 See ElLICKSON, supra note 11, at 170-74.

${ }^{155} \mathrm{Cf}$. Tyler, supra note 81 , at $104-05$ (finding a strong focus on procedural faimess even among criminal defendants facing long sentences). For a description of a client in a civil case who expresses subjective preferences in a divorce case that include "fight[ing the] injustice" of an improper restraining order and "an acknowledgment that she has been treated unjustly," while her attorney pushes the case toward an objective value focused on "the real business" of a property settlement, see SARAT \& FELSTINER, supra note 29, at 94. See also Jones v. Barnes, 463 U.S. 745, 759 (1983) (Brennan, J., dissenting) (noting that a litigant may want to "press the argument that he is innocent" despite easier means of victory or "insist on certain arguments for political reasons"); Binny Miller, Give Them Back Their Lives: Recognizing Client Narrative in Case Theory, 93 MiCH. L. REv. 485, 565-66 (1994) (arguing for collaboration between clients and lawyers in formulating case theory and noting clients may choose one theory over another for noninstrumental reasons such as "vindication," "personal integrity," or the chance to "establish an important legal principle").

Noninstrumental concerns play a large role in justice system experiences; people focus on fair processes as much as, or more than, outcomes. See TYLER, supra note 81, at 101, 112, 116. Procedural justice is the primary influence on judgments about justice processes and satisfaction with third-party decisions. See id. at 107; see also Tom R. Tyler, Psychological Models of the Justice Motive: Antecedents of Distributive and Procedural Justice, $67 \mathrm{~J}$. PERSONALTYY \& SOC. PSYCHOL. 850, 857 (1994). People place high value on "process control," the opportunity to speak to those who control case outcomes in an attempt to influence the decision. See Tom R. Tyler \& Kathleen M. McGraw, Ideology and the Interpretation of Personal Experience: Procedural Justice and Political Quiescence, $42 \mathrm{~J}$. SOC. ISSUES 115, 121 (1986).

156 See BINDER ET AL., supra note 2, at 5-15. Indeed, because people forgo litigation of most legal claims, one might think that those claims that are in fact litigated, at least in some class of cases (torts, for instance), arise because litigants disproportionately place considerable subjective value on vindication beyond formal money or liberty claims. See Richard L. Abel, The Real Tort Crisis-Too Few Claims, 48 OHIO ST. L.J. 443, 447 (1987). 
objectively defined resources. ${ }^{157}$

This point corresponds with broader problems in determining values that affect public policymaking. Expert cost-benefit analysis tends to impose objective assessments of values that conflict with popular, subjective valuations. Values are functions of social contexts from which they cannot be abstracted. ${ }^{158}$ Experts tend to understate the value of "sof" variables. In regulatory policymaking, those may include the value of clean air, better health, and increased auto safety; parties to litigation may have any number of comparably soft values, arising, for example, from dignitary or vindication concerns. ${ }^{159}$

157 Recent scholarship on client counseling and lawyering theory, as well as teaching approaches to those topics, has given some attention to this problem and provides illuminating cases studies. See Clark D. Cunningham, The Lawyer as Translator, Representation as Text: Towards an Ethnography of Legal Discourse, 77 CORNELL L. REV. 1298, 1300-01 \& nn.7-11 (1992) (citing sources); Tanina Rostain, The Company We Keep: Kronman's The Lost Lawyer and the Development of Moral Imagination in the Practice of Law, $21 \mathrm{~L}$. \& SOC. INQUIRY 1017, 1033 \& nn.51-57 (1996) (book review) (discussing sources).

Clark Cunningham has described a misdemeanor criminal matter that held significant dignitary and emotional value for the client. See Cunningham, supra at 1303-31. The client was an African-American man stopped in his car at night by two white policeman. Based on the client's account, the police were excessively rough and rude, stopped him on a pretext because he drove an expensive car, and fabricated a charge of disturbing the peace because the client exercised his right not to cooperate with the officers. See id. Cunningham recounts his own misperception of the client's understanding and valuation of the case. Despite Cunningham's creative attempts to serve his client's preferences, see id. at 1326-28 (recounting a proposal to let the client cross-examine a key witness in a jury trial aimed at "giving him a voice in the courtroom" and achieving his goal of "restoration of his dignity"), the client was extremely dissatisfied with both his lawyer's representation and the substantive outcome, which was objectively very favorable-the charge was dismissed. See id. at 1328 30. In addition to formal exoneration, the client wanted a process that acknowledged the moral wrong done to him by the officers. See $i d$. That strong client preference could be met through the mechanism of a hearing on a suppression motion or a trial. Yet that requires an aftomey not only to learn the subjective preferences of his client but also to honor them by resisting routine strategies for case resolution, routines that may be enforced by norms. See also Caplin \& Drysdale v. United States, 491 U.S. 617, 647 (1989) (Blackmun, J., dissenting) (noting the need for a "maverick" lawyer to resist judges' "preference for nonconfrontational styles of advocacy" enforced by sanctions).

158 See Pildes, supra note 55, at 955-65. See also, e.g., Elizabeth Anderson, Values, Risks and Market Norms, 17 PHII. \& PUB. AFF. 54, 60-62 (1988) (discussing how workers assess workplace risks, and how those assessments vary depending on the particular job and the personal value they place on the work); id. at 959.

159 Similarly, in risk analysis, lay judgments depend much more upon the contextual features in which the risk arises than upon expert judgments, such that quantitatively identical risks are treated differently depending on such factors as whether one has control over exposure to the risk and what benefits one receives from the risky activity. See Richard H. Pildes \& Cass R. Sunstein, Reinventing the Regulatory State, 62 U. CHI. L. REV. 1, 58-61 
Public interests in adjudication are also qualitative and thus hard to value. ${ }^{160}$ One proposal for the problem in regulatory policymaking is improved democratic, deliberative processes that increase consideration of lay valuations that conflict with expert judgment. ${ }^{161}$ In the litigation setting, an analogous response is clientcentered counseling, which gives increased attention to clients' subjective preferences. Practice norms constrain such counseling, and norms themselves often suffer from the same elite bias and lack of democratic deliberation that skews regulatory policies.

Moreover, client wishes are themselves contingent on the context of the client's problem and the attomey-client relationship. The client's choices among legal strategies and entitlements depend significantly on the attorney conveying information and expertise and on exploring with the client the legal and nonlegal implications of various options. 162 Client preferences often are not firm prior to counseling; lawyers cannot simply effectuate expressed wishes. ${ }^{163}$ A premise of client-centered counseling, as well as competing conceptions of the legal counseling that urge lawyers to more explicitly raise moral implications of client choices, ${ }^{164}$ is that client preferences are endogenous to the attorney-client

(1995). Extending that pattern to choices for trial, parties will vary in their willingness to forgo settlement and risk a trial according to background issues of their cases. Trials with the same expected utility (favorable outcome discounted by the chance of loss) will be more or less appealing to clients based not only on personal tastes for risk but also on varying desires to argue publicly the contexts of legal issues. For ethnographic evidence of attorneys who objectify and reshape client preferences, see generally SARAT \& FELSTINER, supra note 29 (documenting attomey-client relations in divorce cases).

160 See Resnik, supra note 35, at 430 (identifying public "values of due process" to include "the accuracy of decisionmaking, the adequacy of reasoning, and the quality of adjudication').

161 See Pildes, supra note 55, at 955-66; Pildes \& Sunstein, supra note 159, at 58-61.

162 Clients thus face a version of the imperfect-information problem. See COOTER \& ULEN, supra note 149 , at 48 .

163 Even if clients come to the lawyer with firmly set preferences, the lawyer has a professional obligation to ensure that the client has arrived at that choice with full consideration of all options and consequences. See BNDER ET AL., supra note 2, at 16-23. More broadly, preexisting client choices are suspect for the reasons expressed that preferences generally are suspect: they may be a function of the client's pre-existing wealth endowment. The client may prefer another option if she knew it to be within her means. See COOTER \& ULEN, supra note 149, at 23; Pildes \& Sunstein, supra note 159, at 76-80.

164 Scholars including Anthony Kronman urge the counseling process to be one in which the lawyer employs moral imagination to assume the client's perspective and deliberates with the client to clarify-and assess the wisdom of-client preferences. See ANTHONY T. KRONMAN, THE LOST LAWYER 132-33 (1993); see also THOMAS L. SHAFFER \& ROBERT F. COCHRAN, JR., LAWYERS, CLIENTS, AND MORAL RESPONSIBIITY 40-54 (1994) (discussing the role of "lawyer as friend" as similar to Kronman's view); Rostain, supra note 157, at 1027-33 (discussing and criticizing Kronman's approach). 
relationship 165 (thus the risk of diminishing client autonomy in counseling). Yet information and advice can rarely be conveyed neutrally; it will contain the attorney's subjective perspective, either consciously or unconsciously. ${ }^{166}$ Practice norms can have tremendous if subtle effects on client counseling as well as on choices the attomey typically makes (for example, discovery motions) without client input. Lawyering literature ${ }^{167}$ reveals that even well-intentioned attorneys have difficulty understanding clients' subjective preferences and fulfilling them in light of norms that undermine legal entitlements. ${ }^{168}$ Norms,

165 See BINDER ET AL., supra note 2, at 16-23; see also KRONMAN, supra note 164, at 128-34 (discussing the role of lawyers in shaping and clarifying client goals); William $\mathrm{H}$. Simon, Lawyer Advice and Client Autonomy: Mrs. Jones's Case, 50 MD. L. REv. 213, 217-18 (1991) (describing how client preferences can change in response to subtle rephrasing of attomey advice); SPANGLER, supra note 81, at 60 (describing an attomey who notes "“[ $t]$ he sad fact is... I can essentially make it [a client's business decision] myself by presenting the choices in a sufficiently slanted way"'). This is not to suggest that clients do not have strong preferences independent of their lawyers' counsel. Evidence is clear that many do, and that attomey counseling may ignore these preferences or coercively persuade clients against them. However, an absolute baseline of "client preference," to which an attomey can neutrally offer information and then effectuate a client's preference, is often not a useful conception of the situation.

166 See Dinerstein, supra note 152, at 567-69 (discussing the "numerous problems" advice-giving presents for lawyers committed to fostering client autonomy, including premature advice that "may prevent the client from making her own choice in her own way").

167 See, e.g., SARAT \& FELSTINER, supra note 29, at 94 (recounting a client's statements to her lawyer in a divorce case that she wanted to "fight [the] injustice" of an improper restraining order imposed on her and how she looked to her attorney to "protect [her] from horrible things like judicial abuse[,]" while for the attomey, "that kind of justice simply gets in the way of what for him is the real business of divorce: to reach a property settlement, not to right wrongs or vindicate justice"); id. at 114-15 (describing the same client reminding her attorney that "a reasonable property settlement ... is not her exclusive concern" and seeking to "expand[] the law's agenda" to seek "vindication," which the attorney views as "a peripheral concem"); see also GRETA BRD, THE PROCESS OF LAW IN AUSTRALIA: INTERCULTURAL PERSPECTIVES 196-98 (2d ed. 1993) (noting the widespread tendency in Australian courts of barrister dominance and control of the client, treating as routine and fungible matters that, to clients, are highly emotional and individual); Michelle S. Jacobs, Legal Professionalism: Do Ethical Rules Require Zealous Representation for Poor People?, 8 ST. THOMAS L. REV. 97, 101 (1995) (arguing that routine cases for lawyers are, from the client's view "hardly routine"); Miller, supra note 155, at 552-70 (urging client participation in case theory and planning, both for instrumental advantages in litigation and to serve a normative preference for client control of their own cases).

168 While most of the data I use here involves criminal practice, research indicates civil parties are just as likely to have subjective preferences that attomeys are likely to undervalue. See generally SARAT \& FELSTINER, supra note 29 (documenting divorce clients' preferences, which are often altered or ignored by attomeys). Conley and O'Barr, in their study of litigants in small claims courts, characterize many parties as "relational," focusing on the social context 
built upon objective valuations of claims and of procedural entitlements, further hinder attorneys' abilities to be guided by clients' wishes; they perpetuate lawyers' objectification of client claims. ${ }^{169}$ Professional socialization, of which norms are a central tool, reinforces the practice. ${ }^{170}$ Instead of mediating client ends in light of public norms that inhere in law, lawyers must mediate them with regard to norms that may subvert law's public commitments. Moreover, even when attorneys overcome the tendency to objectify claims and are committed to client-centered practice, norms hinder them from doing so. In a norm setting, the attomey's choice is not one between equally available strategies; counsel face resistance from other lawyers and judges who enforce norms ${ }^{171}$ (in addition to case load or resource pressures that also discourage client-centered practice). ${ }^{172}$

and relationships of the dispute. This perspective seems to correlate with parties who have stronger process preferences and are less likely to agree with objective valuation of the cases. See JOHN M. CONLEY \& WLIIAM M. O'BARR, RULES VERSUS RELATIONSHIPS: THE ETHNOGRAPHY OF LEGAL DISCOURSE 58-61 (1990); $i d$. at 127-31 (describing a contract case in which the plaintiff won a default judgment and the judge concluded "she got everything she wanted," while the plaintiff indicated that she was "furious [that she] didn't get to tell" her story).

${ }^{169}$ Constructing a client's goals objectively serves professional players' self-interest. It is easier to formulate objective goals for a given type of dispute-because each similar dispute becomes close to fungible-than to spend additional time determining each client's subjective preferences and then tailoring litigation strategies to pursue them. (Lawyers for wealthy clients are highly paid in part to provide this sort of customized lawyering.) If claims and client demands are sufficiently similar, attomeys and courts can improve efficiency by standardizing the processing of cases. See Gary Bellow, Turning Solutions into Problems: The Legal Aid Experience, 34 NLADA BRIEFCASE 106 (1977) (noting that legal services lawyers responded to case pressures and cut case processing time by narrowly and objectively defining client interests and disfavoring client autonomy).

170 On socialization, see Tyler \& McGraw, supra note 155 , at 123-24. See also HEUMANN, supra note 16, at 89-90 (describing the socialization of defense attomeys in early practice); NARDULLI, supra note 42, at 156-57; Nelson \& Trubek, supra note 7, at 175, 188.

171 Cunningham's case provides an example: when faced with a client and defense attomey who invoked full procedural entitlements to vindicate subjective wishes at stake in a minor ticket, the prosecutor and judge dismissed the case as not worth the trouble. See Cunningham, supra note 157 , at 1328-29, 1372. This calculation hinged on the case's objective value (the likely sentence was a $\$ 50$ fine), on disregard for the subjective utility arising from procedural justice and dignitary concerns, and on disregard for public interests, which might include clarifying whether police abuse occurred and a demonstration that such abuse will come to light in court, rather than be governed by a sort of "de minimus norm" pursuant to which such conduct is ignored in the context of minor offenses.

${ }^{172}$ Cf. Jacobs, supra note 167, at 101; Menkel-Meadow \& Meadow, supra note 82, at 243 (noting the risk for lawyers that "[i]f the stakes are high, the [client's] problems can become complex. If the client lacks money, his problems are likely to become routine."); Pepper, supra note 151, at 631 (noting that one barrier to moral dialogue among attorneys and clients is the expense of that practice, because an attomey's time is money). 
Legal education's efforts to foster this approach confront a formidable obstacle from practice norms that govern many practice settings for low income parties. The pedagogy of client-centered counseling, and attomeys' individual commitments to it, are likely to have most of their effects outside arenas of practice regulated by norms and in those moments within practice when attorneys have counseling and strategic options in spite of practice norms. Ethical rules and legal training are relatively weak tools with which to confront norms strongly enforced by local work groups, at least at the level of individual attorney conduct. ${ }^{173}$

\section{B. Public and Third-Party Interests}

Against the dominant conception of the lawyer as solely the servant of client autonomy stands a competing argument that lawyers also have a broader, public role to serve public interests of justice and systemic interests of judicial administration, including the equitable distribution of legal resources. ${ }^{174}$ Despite the formal duty to represent clients zealously and with undivided loyalty, other considerations inevitably affect lawyering actions; lawyers should conscientiously confront that tension. ${ }^{175}$ Legal ethics scholars have examined a range of approaches that attorneys should employ to weigh such competing concerns. William Simon recently refined his work on ethical discretion in lawyering in his book, The Practice of Justice: A Theory of Lawyer's Ethics, ${ }^{176}$ which offers the most deliberate strategy to the problem of weighing public, third-party, and attorney interests against the client's wishes and merits of her case. Simon argues that lawyers should calibrate their professional conduct based on their assessments of the internal merit of the client's case, its relative merit with regard to competing social concerns, and the lawyer's ability, relative to other institutional actors, to help achieve substantive justice in the case. ${ }^{177}$ With

173 I discuss below the possibilities for reforming norms and suggest coordinated group action is the most promising approach in a difficult battle. See infra notes 202-21.

174 See KRONMAN, supra note 164, at 118, 134-46 (discussing lawyers' cooperative role with judges to effectuate public norms in law); Simon, supra note 73, at 1092-94.

175 One suspects that one cause for distinction between client-autonomy models and ethical-discretion models is that their proponents have in mind different lawyers and clients. The ethical-discretion model is especially appropriate for elite lawyers serving wealthy clients; those lawyers are most likely to be excessively loyal to client interests. Public defenders or poverty lawyers are at risk for the opposite tendency, and the client-centered model aims to ensure that they give sufficient loyalty to clients.

176 See generally SIMON, supra note 1.

177 See id. at 138-42; see also Simon, supra note 73, at 1090-1119 (developing the argument in the context of civil litigation); see generally William $\mathrm{H}$. Simon, The Ethics of Criminal Defense, 91 MICH. L. REV. 1703 (1993) (making comparable arguments with regard 
somewhat different emphasis, Dean Anthony Kronman has urged that lawyers adopt a "cooperative role" with judges in advancing "the administration of justice" and the legal system's "integrity" and "well-being" by mediating law's "public norms" with client interests. 178

Practice norms often represent a tacit integration of interests other than the client's into the lawyer's (and judge's) decisionmaking. ${ }^{179}$ They frequently reflect choices about how to allocate scarce legal resources based on conceptions of substantive justice as well as attomeys' and judges' self-interest or ideological preferences. In that sense they reflect one means of serving Simon's or Kronman's goals, but this Article has shown how they imply judgments that do not fit even these broader models of the lawyer's role.

This Article has noted that some norms strike these balances in more defensible ways than others. A limited version of the trial-penalty norm, for example, can be a legitimate response to the conflict between the judicially created entitlement and the legislature's underfunding of that right. The doctrine asserts the public value of jury trials with full resources, while the legislature counters with a judgment that holds that value in much less regard. Under Simon's or Kronman's conception, lawyers legitimately can confront this tension and make substantive choices about resolving it in a manner that does not serve only the interests of the current, individual client. Yet to the extent lawyers extend the norm to serve interests and values beyond the competing ones offered

to criminal practice). But see SHAFFER \& COCHRAN, supra note 164 , at $32-34,56-58$ (discussing and criticizing Simon's approach).

178 See KRONMAN, supra note 164 , at 118, 134-46. Other scholars have argued that lawyers should discuss effects that the case may have on the public interest and third parties with the client. These approaches similarly seek to adjust strategic lawyering decisions in light of concerns other than the client's best interests, but they urge the lawyer to be a force of moral suasion and should do so only with the client's assent. See SHAFFER \& COCHRAN, supra note 164 , at 40-54 (arguing for a model of counseling in which the lawyer acts as the client's "friend," raising moral issues); Kimberly E. O'Leary, Creating Partnership: Using Feminist Techniques to Enhance the Attorney-Client Relationship, 16 LEGAL STUD. F. 207 (1992) (arguing for more client input in lawyering decisions that involve nonclient interests). Additionally, Anthony Alfieri, in a series of provocative articles arguing for the relevance of race-conscious judgment in criminal practice, offers a defense attomey's duty to consider public or community interests in racially charged criminal cases. See generally Anthony V. Alfieri, Lynching Ethics: Toward a Theory of Racialized Defenses, 95 MiCH. L. REV. 1063 (1997); Anthony V. Alfieri, Race Trials, 76 TEx. L. REV. 1293 (1998); Anthony V. Alfieri, Race-Ing Legal Ethics, 96 ColUM. L. REV. 800 (1996).

179 Corporate governance law mediates an analogous tension for managers between pursuing exclusively the shareholders' interests and other stakeholders in the corporation such as suppliers, employees, and the local community. (Some state statutes explicitly encourage consideration of the latter interests.) See generally Symposium, New Directions in Corporate Law, 50 WASH. \& LEEL. REV. 1373 (1993). 
by appellate courts and legislatures-to the extent a norm constricts trial access to serve attorneys' or judges' self-interest or preference ${ }^{180}$ - the norm does not embody legitimate judgments even within Simon's or Kronman's approaches.

In contrast, the fair-dealing norm, while it superficially resonates with substantive justice considerations that are legitimate concerns in Simon's model, in fact is illegitimate even on this view. There is little indication that the defense lawyer is much better positioned than other players or the system generally to achieve substantive justice, one of Simon's key criteria for departing from purely client-focused practice. ${ }^{181}$ To the extent such a practice (which, recall, entails a defense lawyer offering a harsher punishment for her client) reflects the assessment of the merits of a client's case that Simon calls for, ${ }^{182}$ it points to the risks for misuse of ethical discretion. The fair-dealing norm suggests how merit assessment of a client's case becomes conflated with lawyer self-interest or perversion of professional role.

Norms, then, are an unreliable mechanism for accommodating the competing interests that the ethical discretion model puts in lawyers' hands. That model places responsibility on individual attorneys, who must make new ethical judgments for each. Norms remove those discretionary judgments both from the attorney and the from the level of case-by-case decisionmaking. Difficult moralpolitical calculations are resolved through norms that govern entire classes of cases and clients. Norms, like legal rules, are general standards that do not fit all specific cases well. ${ }^{183}$ They set presumptive policies with little regard for the relative, competing concerns within each case, the locus at which ethics scholars focus the decision. ${ }^{184}$ Norm judgments are made by insular professional communities ill-suited for either public, deliberative decisionmaking, or the moral-professional judgment called for by Simon's discretionary approach. Attorneys committed to an ethical practice in conflict with norms can do so only

180 See supra note 129 and accompanying text (discussing Lynch's study of two counties with widely varying trial rates attributable largely to local norms).

181 See SIMON, supra note 1, at 140 ("T] he more reliable the relevant procedures and institutions, the less direct responsibility the lawyer need assume for the substantive justice of the resolution; the less reliable the procedures and institutions, the more direct responsibility she needs to assume for substantive justice.").

182 See id. at 50-51, 138-39.

${ }^{183} C f$. Resnik, supra note 35 , at 408,419 (noting that managerial judging relies on generalizations that do not fit all cases well). Mediating the fit between general rules and specific cases and contexts is the task of statutory interpretation. See generally WILLIAM N. ESKRIDGE, JR, DYNAMIC STATUTORY INTERPRETATION (1994).

184 The Supreme Court has also stated that "wide latitude" for individualized judgment rather than "detailed guidelines" or a "checklist" for lawyering decisions is essential for defense counsel. See Strickland v. Washington, 466 U.S. 668, 688-89 (1984). Strong norms, like formal mandates, could diminish that range for judgment. 
at a cost. Yet ethical discussions generally give little attention to such structural factors that have tremendous effects on attorney practice choices. ${ }^{185}$

\section{EXPLANATIONS FOR NORMS AND BARRIERS TO REFORM}

\section{A. Behavioral Explanations for Norms}

\section{1. "Herd Behavior" Model}

There is often little incentive to change from an orderly consensus, ${ }^{186}$ particularly when attomeys have constructed notions of justice to privilege existing practices, and when resources partly do constrain some practices. Behavioral psychology suggests a couple of ways that norms maintain their force. According to a model of "herd behavior," actors tend to reduce reputational costs by opting for standard practices, to some extent ignoring their own information and judgment. ${ }^{187}$ If the choice is wrong, at least one is not wrong alone; the choice was a widely selected one, which confirms its ex ante prudence. ${ }^{188}$ For example, a norm that entitles one to a trial only for reasonable disputes makes the trial option risky. The attorney risks not only the sanction of the trial penalty (borne by the client) but also the reputational injury of displaying poor judgment (or poor "client control") 189 that "wastes" public resources. There is little reputational cost, in contrast, to urging a plea or bench trial, which are not only more common but-in the case of pleas-resolve the case such that evidence will not usually come to light to prompt reassessment of the attorney's advice. ${ }^{190}$ The risks and payoffs to the lawyer are asymmetrical. The potential

185 Simon makes brief reference to financial constraints that some lawyers face in deciding whether to accept clients and how to litigate their cases. See Simon, supra note 73, at 1094. For accounts documenting the effects that practice settings and lawyer incomes have on ethical conduct and how client-centered a lawyer's practice is, see generally HENZ \& LAUMANN, supra note 81.

186 See NARDULLI ET AL., supra note 15, at 324 ("Once a consensus has been forged in a community, there is little desire, or incentive, to improve upon it. Not only would that take time and effort, but also by adhering to the standard disposition for the routine case, "no one gets hurt too badly."'); Galanter, supra note 147, at 117.

187 See, e.g., Abhijit Banaerjee, A Simple Model of Herd Behavior, 107 Q.J. ECON. 797 (1992).

188 See David Millon, Default Rules, Wealth Distribution, and Corporate Law Reform: Employment at Will Versus Job Security, 146 U. PA. L. REv. 975, 1033 (1998).

189 The desirability of "client control" among attomeys in local courts is widely documented. See, e.g., BIRD, supra note 167, at 196-97; FLEMMING ET AL., supra note 16, at 151-52; HEUMANN, supra note 16.

190 Note that in this setting, in contrast to other agency-principal relationships, the agent's 
costs of urging a client to accept a suboptimal plea are less than those of demanding a trial which may end up being deemed "unreasonable" by other professionals. 191

Herd behavior is used to explain a variety of behavior, especially in agency contexts, in which norms are not observed to play any role. ${ }^{192}$ Indeed, one could imagine a regime-as surely exists in many jurisdictions-in which the sanctions enforcing a norm against trials are not strong, but plea bargains are nonetheless commonplace. Herd behavior could still explain (though only in part) a preference for the less risky choice of plea over trial.

However, the herd behavior insight, applied to a setting characterized by norms, reveals an additional function within a norms regime. The reputational cost, against which herd behavior protects, serves as an ancillary sanction to reinforce the norm. The attorney urges a plea not only to avoid a trial penalty imposed on his client and perhaps other sanctions on himself, such as fewer court appointments or reduced cooperation from prosecutors, but also to hedge against the risk of tamishing his reputation among other professionals. The insight applies to other norms as well; herd behavior may increase observance of, say, the discovery-motion or expert-finds norms.

\section{Inertia Theory and Default Practices}

In addition, attomeys like all people demonstrate a "status-quo bias"- they prefer established options or pre-selected practices over ones that must be affirmatively chosen. Building on extensive behavioral psychology research and empirical studies of preferences in contract negotiation, Russell Koroblcin has posited an "inertia theory" that explains preferences for default rules or form contract terms by a more general inclination for inaction over action. ${ }^{193}$ If they

(i.e., the attomey's) main concern is with his reputation with opposing attomeys and judges more than with the principal (the client). Cf. Millon, supra note 188, at 1034 (noting that corporate agents fear innovative decisions because, if they turn out badly, it injures their reputation with their principals). This argument is much weaker, of course, in attomey-client settings in which clients are capable of better monitoring attormeys and have choices among attomeys, and when attomeys depend more on developing reputations with clients.

191 Cf. Marcel Kahan \& Michael Klausner, Path Dependence in Corporate Contracting: Increasing Returns, Herd Behavior and Cognitive Biases, 74 WASH. U. L.Q. 347, 357-58 (1996).

192 See Kahan \& Klausner, supra note 191, at 353-55 (describing attomeys drafting corporate contracts); Millon, supra note 188, at 1033-34 (describing corporate agent's negotiation of job security terms); see also Jeffrey Zwiebel, Corporate Conservativism, Herd Behavior and Relative Compensation, 103 J. POL. ECON. 1 (1995) (describing investment decisions).

193 Korobkin, Inertia and Preference, supra note 5, at 1605. 
care strongly enough for an alternative to a default rule or standard term, people will of course negotiate for it. However, when preferences for alternatives are modest, the status-quo bias can lead many not to act on the preference. When the preferred term is also the default term, the preference becomes much stronger. Korobkin concludes from experimental data that "the bias in favor of default terms is at least partially the result of deeply ingrained psychological instincts that cause us to favor inaction over action, even when doing so is not profit maximizing."194 One implication for contract negotiation is that whichever party is able to define the status quo position with an initial proposal of draft terms will likely enjoy a substantial bargaining advantage. ${ }^{195}$ As is true of the herd behavior thesis, opting for the status quo is one strategy to minimize future regret.

The insight for practice norms is obvious. If one thinks of a given practice shaped by norms as a default practice fashioned by local legal culture, one would expect attorneys to demonstrate a bias in favor of the status quo practice. Consider again the trial norm. Not all clients want trials, but some preferences are shaped by the extreme constriction on trials that prevails among lawyers and judges in many places. However, even the increase in jury trial rates that Lynch found in his comparison of jurisdictions could lead to client choices that are less influenced by practice norms - and to more zealous representation. ${ }^{196}$ Even within tight budgets, jurisdictions could encourage bench trials (or trials by lay magistrates) over pleas simply by moving to a "default practice" of such trials in a large portion of cases. The shift would affect attomey judgment in counseling clients and probably also client preferences as well. Similarly, one would expect to see attorneys much more readily follow the routine of filing discovery motions if that were a standard practice choice encouraged (or just not discouraged) by a norm. As this Article discusses below, these insights suggest some means for reforming norms to foster better practice by attorneys.

\section{Path Dependency}

This explanation accords with "path dependency" theory197 as applied to practice norms. Practices that vary substantially in comparable settings may result from earlier conditions or prior "norm leaders" (for example, a chief judge) who set a standard that continues even as conditions change. At an earlier period, when norm leaders set given norms, expectations were built around them. A jurisdiction came to assume that only, say, three percent of trials would be

194 Id. at 1593.

195 See id. at 1608.

196 See Lynch, supra note 20, at 125-26; see also supra note 129 and accompanying text.

197 See Mark J. Roe, Chaos and Evolution in Law and Economics, 109 HARV. L. REV. $641,653-60$ (1996). 
resolved by jury trials instead of thirty percent. (A normative baseline was inferred from that fact-only three percent should be resolved by juries.) Court budgets and work expectations were set accordingly. Judges felt an entitlement to be on the bench only fifteen hours a week instead of thirty. Court administrators and legislators came to expect $x$ number of cases to be processed by $y$ number of judges. Attorneys accepted as an economic premise of their practices that $x$ number of cases would be resolved quickly. The multiple ways that various players build expectations around that regime and come to rely on it create constituencies against change. ${ }^{198}$ In this way a "path" chosen at an earlier time becomes entrenched.

As Mark Roe has noted, a given path creates a tacit information set; actors have less information about alternatives not chosen. This problem of asymmetric information means a group "cannot think effectively about the alternative path because it lacks the vocabulary, concepts or even belief that the other path could exist."199 Attorneys may be unable to imagine, for example, that more cases could be tried, with fuller discovery, with existing resources. ${ }^{200}$ Status quo practices become harder to change.

\section{B. Social Meaning of Norms}

Practice norms also sustain their force through their social meaning. Norms always have meaning; they show what we value or believe.201 The norm permitting ex parte contacts, for instance, has an important signaling effect. Formal ex parte prohibitions carry a meaning of distrust of the judge (and perhaps also the attorney) engaging in the contact. It implies that the judge will not be fair or decide the case on its merits, merely because he engaged in a conversation about it at some earlier point. It insults the judge's integrity.

198 See Roe, supra note 197, at 651-52 (discussing the "public choice" feature of path dependence and noting that "[w]hen a society chooses one economic path over another, it also creates a political dynamic by making economic incumbents").

199 Roe, supra note 197, at 651 (discussing the information barrier created by path choice); see also ROBERTO MANGAHERIA UNGER, FALSE NECESSITY (1987). This observation seems true even in the context of local court communities, in which there is extensive variation. Although players in one court often need only look to a neighboring county or state for different arrangements, the availability of such information does not translate into an equal choice. The regime in which one was trained and lives is more vivid. In addition, coordination problems - getting multiple actors to be persuaded by the wisdom of a change-remain.

200 See HEUMANN, supra note 16, at 89-91.

201 Scholars have given specific attention to the meaning of norms as attention to norms in legal scholarship has increased. See Dan M. Kahan, Social Influence, Social Meaning, and Deterrence, 83 VA. L. REV. 349, 362 (1997); Lessig, supra note 56, at 997-1007; Lawrence Lessig, Social Meaning and Social Norms, 144 U. PA. L. REV. 2181, 2182-83 (1996). 
similar claims very differently; comparable claims arise in different contexts and implicate different nonlegal consequences. ${ }^{153}$ Just as market prices are in fact only objective approximations of the subjective value of goods to any given contracting party, ${ }^{154}$ the objective value of a legal claim-the money damages in a civil action, or restitution and punishment at issue in a criminal action--are only second-best approximations of a claim's subjective value to a client. Many legal disputes, and the processes used to resolve them, ${ }^{155}$ have significant personal or emotional value to disputants. ${ }^{156}$ A legal strategy motivated by concern for a party's subjective preferences with regard both to outcomes and procedure will often be different from one focused on a rational maximization of

153 See BINDER ET AL., supra note 2, at 3; id. at 5-15 (describing how nonlegal concems can change client preferences on legal strategies and options); cf. Pildes, supra note 55, at 937, 955-59 (discussing how citizen preferences, with respect to goods regulated by public policy, vary with context and cultural values).

154 See ELLICKSON, supra note 11, at 170-74.

$155 C f$. Tyler, supra note 81 , at $104-05$ (finding a strong focus on procedural faimess even among criminal defendants facing long sentences). For a description of a client in a civil case who expresses subjective preferences in a divorce case that include "fight[ing the] injustice" of an improper restraining order and "an acknowledgment that she has been treated unjustly," while her attomey pushes the case toward an objective value focused on "the real business" of a property settlement, see SARAT \& FELSTINER, supra note 29, at 94 . See also Jones v. Bames, 463 U.S. 745, 759 (1983) (Brennan, J., dissenting) (noting that a litigant may want to "press the argument that he is innocent" despite easier means of victory or "insist on certain arguments for political reasons"); Binny Miller, Give Them Back Their Lives: Recognizing Client Narrative in Case Theory, 93 MrCH. L. REV. 485, 565-66 (1994) (arguing for collaboration between clients and lawyers in formulating case theory and noting clients may choose one theory over another for noninstrumental reasons such as "vindication," "personal integrity," or the chance to "establish an important legal principle").

Noninstrumental concerns play a large role in justice system experiences; people focus on fair processes as much as, or more than, outcomes. See TYLER, supra note 81, at 101, 112, 116. Procedural justice is the primary influence on judgments about justice processes and satisfaction with third-party decisions. See id. at 107; see also Tom R. Tyler, Psychological Models of the Justice Motive: Antecedents of Distributive and Procedural Justice, $67 \mathrm{~J}$. PERSONALTTY \& SOC. PSYCHOL. 850, 857 (1994). People place high value on "process control," the opportunity to speak to those who control case outcomes in an attempt to influence the decision. See Tom R. Tyler \& Kathleen M. McGraw, Ideology and the Interpretation of Personal Experience: Procedural Justice and Political Quiescence, $42 \mathrm{~J}$. SOC. ISSUES 115, 121 (1986).

156 See BINDER ET AL., supra note 2, at 5-15. Indeed, because people forgo litigation of most legal claims, one might think that those claims that are in fact litigated, at least in some class of cases (torts, for instance), arise because litigants disproportionately place considerable subjective value on vindication beyond formal money or liberty claims. See Richard L. Abel, The Real Tort Crisis-Too Few Claims, 48 OHro ST. L.J. 443, 447 (1987). 
objectively defined resources. ${ }^{157}$

This point corresponds with broader problems in determining values that affect public policymaking. Expert cost-benefit analysis tends to impose objective assessments of values that conflict with popular, subjective valuations. Values are functions of social contexts from which they cannot be abstracted. ${ }^{158}$ Experts tend to understate the value of "sof" variables. In regulatory policymaking, those may include the value of clean air, better health, and increased auto safety; parties to litigation may have any number of comparably soft values, arising, for example, from dignitary or vindication concerns. ${ }^{159}$

157 Recent scholarship on client counseling and lawyering theory, as well as teaching approaches to those topics, has given some attention to this problem and provides illuminating cases studies. See Clark D. Cunningham, The Lawyer as Translator, Representation as Text: Towards an Ethnography of Legal Discourse, 77 CORNELL L. REV. 1298, 1300-01 \& mn.7-11 (1992) (citing sources); Tanina Rostain, The Company We Keep: Kronman's The Lost Lawyer and the Development of Moral Imagination in the Practice of Law, 21 L. \& SOC. INQURY 1017, 1033 \& nn.51-57 (1996) (book review) (discussing sources).

Clark Cunningham has described a misdemeanor criminal matter that held significant dignitary and emotional value for the client. See Cunningham, supra at 1303-31. The client was an African-American man stopped in his car at night by two white policeman. Based on the client's account, the police were excessively rough and rude, stopped him on a pretext because he drove an expensive car, and fabricated a charge of disturbing the peace because the client exercised his right not to cooperate with the officers. See id. Cunningham recounts his own misperception of the client's understanding and valuation of the case. Despite Cunningham's creative attempts to serve his client's preferences, see id. at 1326-28 (recounting a proposal to let the client cross-examine a key witness in a jury trial aimed at "giving him a voice in the courtroom" and achieving his goal of "restoration of his dignity"), the client was extremely dissatisfied with both his lawyer's representation and the substantive outcome, which was objectively very favorable-the charge was dismissed. See id. at 132830. In addition to formal exoneration, the client wanted a process that acknowledged the moral wrong done to him by the officers. See id. That strong client preference could be met through the mechanism of a hearing on a suppression motion or a trial. Yet that requires an attomey not only to learn the subjective preferences of his client but also to honor them by resisting routine strategies for case resolution, routines that may be enforced by norms. See also Caplin \& Drysdale v. United States, 491 U.S. 617, 647 (1989) (Blackmun, J., dissenting) (noting the need for a "maverick" lawyer to resist judges" "preference for nonconfrontational styles of advocacy" enforced by sanctions).

158 See Pildes, supra note 55, at 955-65. See also, e.g., Elizabeth Anderson, Values, Risks and Market Norms, 17 PHIL. \& PUB. AFF. 54, 60-62 (1988) (discussing how workers assess workplace risks, and how those assessments vary depending on the particular job and the personal value they place on the work); id. at 959.

${ }^{159}$ Similarly, in risk analysis, lay judgments depend much more upon the contextual features in which the risk arises than upon expert judgments, such that quantitatively identical risks are treated differently depending on such factors as whether one has control over exposure to the risk and what benefits one receives from the risky activity. See Richard H. Pildes \& Cass R. Sunstein, Reinventing the Regulatory State, 62 U. CHI. L. REV. 1, 58-61 
more judicial involvement, and rising case loads that prompted concern about docket backlogs and efficient disposition. Resnik emphasized the costs of these practices, however, which include judicial action that shapes disposition outside of public or appellate scrutiny, sub silentio rule changes, a reduced emphasis on due process values, unmeasured trade offs of quality for efficiency, and the risk of judicial bias stemming increased power and informal information gathering. ${ }^{211}$ Another widespread development in civil litigation, alternative dispute resolution, also stems in large part from increasing disfavor of adversarial procedure. ADR critics have emphasized prospects that informal approaches may be coercive, particularly among parties with unequal power, and that such methods lead to less concern for substantive rights and justice. ${ }^{212}$ Other than commercial arbitration, ${ }^{213}$ ADR mechanisms were developed disproportionately for lower income parties and others with traditionally less access to the justice system. Moreover, ADR emerged just as these groups were gaining unprecedented access to courts in the 1960s and 1970s as a result of civil rights, consumer rights, and legal aid movements; they were making gains there. ${ }^{214}$ In some contexts, ADR restricts the power that such litigants found in the legal process. 215

Practice norms in criminal courts share much with these civil practice developments. Norms imply a similar disfavor for the legal entitlements available to non-elite litigants. Like ADR, norms are most pervasive in those court settings that serve low income parties. (Their wealthier opponents with larger volumes of litigation, such as landlords or creditors, were the constituency that most favored ADR.) Norms facilitate the same trade off of public and party values for speedy case disposition. ${ }^{216}$ They carry similar risks to ADR and

211 See id. at 380, 407, 414, 426, 430-31 \& 440; see also Fiss, supra note 64, at 1088-89.

212 See Richard Abel, The Contradictions of Informal Justice, in THE POLITCS OF INFORMAL JUSTICE 7-13, 270 (Richard Abel ed., 1982); AUERBACH, supra note 207, at 124; Trina Grillo, The Mediation Alternative: Process Dangers for Women, 100 YALE L.J. 1545 (1991); Nader, supra note 208.

213 Commercial arbitration is now largely viewed as a successful mechanism for disputes among firms, though parties tend to have substantial and roughly equal resources. Auerbach has argued that the system evolved early in the century among corporations to evade the strictures of formal law and resolve disputes within the shared values and interests of the business community, eventually meeting public resistance. See AUERBACH, supra note 207, at $101-14$

214 See id. at 97-100, 124; Nader, supra note 208, at 2-4.

215 Trina Grillo, for example, in a prominent article, stressed the dangers to women in family mediation, which she described as a coercive process hidden from public view that masks inequities of power and responsibility. See Grillo, supra note 212.

216 Cf. Nader, supra note 208, at 2-3 (discussing the concept of "intense influence" to which "[e]ven lawyers and judges may be subjected," that encourages the view of formality, 
managerial judging and often occur even further beyond public scrutiny. ${ }^{217}$

This Article does not mean to imply here a broad condemnation of ADR, just as criticism of norms does not entail opposition to all informal process or settlement (nor do Resnik's criticisms of managerial judging condemn all negotiation and settlement). One cannot assert with confidence that formal or informal process, adversarial or cooperative models, always will be superior over a range of cases and contexts. Courts can be alienating and inaccessible, but they can also be powerful tools for parties otherwise lacking power. Informal forums can increase access and innovate relational, dialogic disputing processes, but they can also be coercive processes that deprive parties of procedural protections, obscure justice claims, and hide the substantive standards that guide case resolutions. ${ }^{218}$ Practice norms pose similar threats (and promises) that must be evaluated in context, but it is clear that they sometimes undermine important public values and deprive parties of beneficial entitlements.

The shift in the content of both professional role and formal process in all three developments are characteristic of "harmony models" of law, which substitute trust, conciliation, informality, and reciprocity for adversarial disputing and overt conflict. Legal anthropologist Laura Nader describes "harmony ideology" as "a rhetoric of peace through consensus" and "the belief that harmony in the guise of compromise or agreement is ipso facto better than an adversary posture."219 Jerold Auerbach has traced recurring turns toward harmony models over adversarial formality in American legal history and has described its use (and the "deleterious effects of coerced informality") for freed slaves after the Civil War, factory workers at the turn of the last century, and for the inner city poor in recent decades through ADR.220

Harmony models depend upon a context, shared by disputants, of trust, rough equality of power, and shared substantive values. Parties mediate claims through a common set of justice commitments that are important enough to them that they may forgo some portion of their claims (which they could vindicate with adversarial means) to sustain them or serve a larger, common interest. ${ }^{221}$ When those justice values arise from within the parties' community, informal approaches can be empowering. ${ }^{222}$ When their source is outside the parties'

rights, and adversary process as bad and conciliatory cooperation as good).

217 See Abel, supra note 212, at 267; Nader, supra note 208; Resnik, supra note 58.

218 See Abel, supra note 212, at 267; Nader, Harmony Models, supra note 207, at 50-53. 219 See Nader, supra note 208, at 1, 3 (emphasis added).

220 See AUERBACH, supra note 207, at 145-46.

221 See id. at 4, 16, 145-46.

222 See GREENHOUSE, supra note 207 (describing a small town religious community's aversion to conflict, formal law, and adversarial justice in the name of shared, faith-based conciliation); NADER, supra note 207, at 1-9 (concluding from a study of Talean Zapotec 
community or they mask inequities of power, however, harmony models can have a repressive effect, because the justice values that guide dispute resolution conflict with parties' interests or public values. ${ }^{223}$

This is the risk with practice norms created by professionals without parties' input. 224 The justice notions with which lawyers imbue practice norms fill the role of the substantive baseline on which consensus is achieved. Those notions, however, are not always shared by litigants or formal law. Norms may restructure adversary processes and attomey-client relationships to produce the same disadvantages that other harmony models, including many forms of $A D R$, have on parties with little power. ${ }^{225}$ In the name of underlying justice standards, harmony models of law sometimes suppress conflict and a party's efforts to vindicate its position. ${ }^{226}$ This move is not per se condemnable, if lawyers are only confronting a conflict between a formal entitlement like the jury trial right and underfunding for that right. Often, though, norms are not solely resourcedriven or based on justice commitments grounded in public values. ${ }^{227}$ In line with harmony models, norms pacify advocates working in an adversary system

communities in Mexico that harmony models are a means to resist domination from outside colonial forces). Another example is commercial arbitration, first created by business interests after World War I. That system can be viewed as commercial interests' attempt to resist control of law with a dispute resolution regime devised from the shared values and interest of the business community. When public sentiment grew less trusting of business in the Great Depression and wanted to ensure more control and supervision, private arbitration was forced to give way to formal law. See AUERBACH, supra note 207, at 101-14.

223 See Grillo, supra note 212; Nader, supra note 208, at 5. Harmony models can have any variety of political effects or ideological uses, just as adversarial models can. Nader, among others, has criticized the ADR movement as a means to pacify and contain the assertion of rights and claims for justice zealously pursued by less powerful groups (racial minorities, women, environmentalists) in the 1960s. See Nader, supra note 208, at 2; Laura Nader, Controlling Processes: Tracing the Dynamic Components of Power, 38 CURRENT ANTHROPOLOGY 711, 713-14 (1997) [hereinafter Controlling Processes]; Laura Nader, The Crown, the Colonialists, and the Course of Zapotec Village Law, in HISTORY AND POWER IN THE STUDY OF LAW 320, 334-39 (June Starr \& Jane F. Collier eds., 1989) [hereinafter Village Law].

224 Of course, this is holding aside the influence that wealthier parties have due to their financial control over attomeys. See discussion infra Part V.D.1.

225 Cf. Caplin \& Drysdale v. United States, 491 U.S. 617, 647 (1989) (Blackmun, J., dissenting) (arguing the need for "the maverick and the risk taker" defense attomey who "might displease a judge [with a] preference for nonconfrontational ... advocacy").

226 See Nader, Harmony Models, supra note 207, at 52 (summarizing studies).

227 Recall that the fair-dealing norm is a clear sell out of the client for collegial notions of justice. See supra Part III.D. Also, what attomeys in Engel's study viewed as "fair" and "mature" norms of tort settlement that left people "largely more happy" conflicted with the views of tort plaintiffs themselves, many of whom felt that their settlements were too low. See Engel, supra note 136, at 854 . 
and repress clients' claims. ${ }^{228}$

\section{Inadequate Constraints on Norms}

\section{Agency Problems}

The preceding explanations suggest how norms are sustained. Yet at least two mechanisms should limit their detrimental effects. One check on norms that harm client interests is clients themselves. However, while agency problems abound in attorney-client relations, they vary considerably with the type of client and the practice setting: lower income clients are more likely to suffer the detrimental effects of practice norms.

Incentives for lawyers to serve client interests vary tremendously.229 Clients who have ongoing relationships with attomeys and are more capable of monitoring their counsel suffer fewer agency costs, ${ }^{230}$ especially if they offer repeat business. Wealthy clients have more control of their attorneys, ${ }^{231}$ who in turn have the least autonomy from clients and are least likely to compromise

228 See Nader, Harmony Models, supra note 207, at 50-53. ADR has been lauded as a relational, empowering, and less stressful altemative to the alienating hostility and formality of adversarial legal processes. Yet it has also been criticized as replicating and aggravating power imbalances among parties. See, e.g., Grillo, supra note 212 (criticizing ADR for forsaking justice claims for conciliation and becoming a tool to pacify aggressive assertion of rights from less powerful and disenfranchised groups); see also, e.g., Abel, supra note 212, at 304-06; Nader, Controlling Processes, supra note 223, at 713-14. This is not to say that adjudication, though sometimes a powerful mechanism for assertion of rights, justice claims, or resistance to the state, cannot also be alienating, an inadequate vehicle for articulating viewpoints, and insufficiently accessible to the poor or powerless. See AUERBACH, supra note 207, at 12 (quoting William H. Simon, The Ideology of Advocacy: Procedural Justice and Professional Ethics, 1978 WISC. L. REv. 29, 115).

229 Judges have different but partly analogous structural influences that encourage selfinterested action; practice norms help them save time, reduce work load, conserve court budgets, and manage dockets by which they are evaluated. See BAUM, supra note 46 , at 44-47, 55 (discussing the influence of judges' goals on reducing work loads); see also id. at 23-44, 47-56 (discussing other influences on judicial behavior including court audiences, legal policy, career concems, and court situations). Those factors help explain judicial use of practice norms.

230 See KRITZE, supra note 16, at 126 (noting that "more sophisticated clients (generally repeat player organizations) of hourly fee lavryers" exert more control over their counsel than other clients).

231 See HEINZ \& LAUMANN, supra note 81, at $104-09$ (noting that the most prestigious lawyers have the least control over their clients, while legal services attomeys and others serving low income individuals are more likely to dictate to clients or operate free of close client supervision); KRITZER, supra note 16, at 126; SARAT \& FELSTINER, supra note 29, at 2021 (reviewing literature). 
client interests. ${ }^{232}$ The wealthy client's future value to the attorney and ability to replace the attorney in the legal services market make it worthwhile for the attorney to defect from the courthouse group, breach norms, and perhaps suffer whatever cost may be incurred as a result. ${ }^{233}$ Also, elite attorneys typically bill wealthy clients at hourly rates. While that creates an incentive to overlitigate, lawyers are also more likely to be attuned to clients' subjective preferences than attorneys who serve lower income clients and are paid a flat salary, appointment fee, or contingency fee. ${ }^{234}$ As a result, one expects fewer agency costs and anticlient norms in elite settings. 235

In practices dominated by lower income clients, in contrast, clients are much

232 See, e.g., ROBERT L. NEL SON, PARTNERS WTTH POWER 269, 286 (1987). Allegiance to a client's interest should not be confused with client-centered counseling. The latter is a process of ensuring that clients have considered all legal and nonlegal options for action, and legal and nonlegal consequences of those options, to arrive at a decision unaffected by the attomey's preferences or values. Attomeys could still view themselves as fully dedicated to client interests without facilitating client autonomy and decisionmaking in this manner. Nonetheless, a commitment to client interests, along with the relative wealth of some clients (because clientcentered counseling is time consuming and costly, see Dinerstein, supra note 152, at 577-78), should make client-centered counseling easier to practice. Yet behavioral biases may affect attomey decisionmaking and lead to suboptimal representation even for these clients. See Kahan \& Klausner, supra note 191, at 352-64.

233 The value of the client's business reduces the differential between reward for cooperation and punishment for defection to the point at which defection is more rational. See Posner, supra note 106, at 139-42. Further, because even sophisticated clients may have difficulty distinguishing between optimal attorney skill and effort on their behalf and case outcomes, they may partially use outcomes to assess their counsel. Because wealthy clients have options in the market for legal services, attomeys should put in more effort to obtain the best outcomes for the client (i.e., forgoing trade offs of attomey self-interest or justice notions).

234 See RICHARD L. ABEL, AMERICAN LAWYERS 204 (1989); SARAT \& FELSTINER, supra note 29, at 20-21 (summarizing several studies); HEINZ \& LAUMANN, supra note 81, at 103-09 (summarizing findings that lawyers in criminal defense practice and other "low prestige" practices are less constrained by client monitoring and ethics than lawyers in elite practice areas such as securities, banking, and general corporate); SPANGLER, supra note 81, at 50 (describing large law firm partners' view of their job as providing "custom tailoring" and "highly individualized" service to provide an "exquisite fit for a particular situation"). These problems are closely related to well-known trade offs of payment methods. See KRITZER, supra note 16; Earl Johnson, Jr., Lawyers' Choice: A Theoretical Appraisal of Litigation Investment Decisions, 15 L. \& SOC'Y REV. 567 (1981).

235 Kronman worries that attomeys confronting competing interests and loyalties will too often yield to the "temptation to resolve [the dilemma] by always putting the client's wellbeing before the law's." KRONMAN, supra note 164, at 145. This temptation is much stronger for lawyers of wealthy clients than those of low income ones, in whose cases countervailing norms often create the bigger problem than excessive client allegiance. On agency problems between lawyers and elite clients generally, see Ribstein, supra note 8, at 1709 \& n.3 (citing sources). 
less effective at keeping their lawyers from taking actions that are suboptimal for the client. They typically lack the skill or experience as repeat players to monitor their lawyers effectively. ${ }^{236}$ Because the attorneys are not economically dependent on the low income client's repeat business, they can pursue divergent interests, such as the need to maintain good relations with other attomeys and judges. A flat salary or per-case fee creates an incentive to minimize time on each case. ${ }^{237}$ Relatively poor clients suffer from the structural setting of their attorneys' workplace ${ }^{238}$ and are more likely to encounter litigation settings with practice norms that infringe on client interests. Practice norms, then, are partly a function of variations in the political economy of practice settings. 239

Agency problems are a focus of corporate law, and the comparison is telling. The traditional assumption is that market competition compels firms to employ a variety of strategic options, such as the primacy of shareholder value over other corporate stakeholders. Yet in fact we find considerable variation in corporate governance choices, along with evidence that preferred choices are not necessarily compelled by markets. ${ }^{240}$ Similarly, one finds wide norm variation

${ }^{236}$ Cf. Richard A. Nagareda, Turning from Tort to Administration, $94 \mathrm{MrCH}$. L. REV. $899,930-38$ (1996) (discussing the effects of agency problems between plaintiffs and attorneys in mass tort actions).

237 See Sonia S. Chan, Note, ABA Formal Opinion 93-379: Double-Billing, Padding and Other Forms of Overbilling, 9 GEO. J. LEGAL ETHICS 611, 627 (1996) (stating that flat fees lead to "standardized, prepackaged groupings of cases" and diminish "individualized and nuanced presentations of fine legal points") (citing Sarah Evans Barker, How the Shift from Hourly Rates Will Affect the Justice System, 77 JudiCATURE 201, 202 (1994)). Conversely, clients paying for their own legal services have an incentive to avoid litigation options of marginal utility. Those not paying their own bills may demand marginal options more often. Norms are one attempt to regulate the latter situation. Legislatively imposed budget constraints on indigent representation are another.

Because they frequently face the same opposing parties, salaried or contingency fee attomeys may trade off present clients' interests and follow practice norms for future good relations with opponents. See H. LAURENCE ROSS, SETTLED OUT OF COURT 80-85 (1980); Johnson, supra note 234.

238 See, e.g., Anthony V. Alfieri, The Antinomies of Poverty Law and a Theory of Dialogic Empowerment, 16 N.Y.U. REV. L. \& SOC. CHANGE 659, 685 (1987-1988) (discussing conventions for "process[ing] individual cases on a mass scale"); Bellow, supra note 169 , at 108 (concluding that excessive case load pressures on legal aid attomeys produced routine processing of cases, diminished client control and autonomy, narrower definitions of client concerns, and inadequate case resolutions).

${ }^{239}$ Cf. Nader, Harmony Models, supra note 207, at 42-44 (reviewing cross-cultural studies on the "political economy of legal models").

240 See Roe, supra note 197, at 646 ("Multiple, equally efficient results might abound...."). 
even within comparable practice settings and client groups. ${ }^{241}$ In contrast to other countries where strong owners are more common, American corporate structures are characterized by weak owners and strong managers. That creates a greater risk of agency costs, because managers may not pursue the shareholders' agenda, and weak owners are less effective at monitoring their agents. ${ }^{242}$ Note the analogy to attorneys and clients. Wealthy clients are strong owners and thus are better at monitoring their agents; they also have more options to change attomeys. Poor clients, in contrast, are weak owners. They have neither effective exit nor voice options. ${ }^{243}$ They cannot leave the local court system nor (in many cases) freely opt for attorney-client relationships with lawyers unaffected by practice norms. ${ }^{244}$ One expects them to suffer more agency costs.

One difference in the comparison, however, is that corporate governance and finance evolved other mechanisms to suppress agency costs and compensate for weak owners-tools such as independent boards, hostile takeovers, and performance-based compensation for managers. ${ }^{245}$ For lawyers' clients, however, nothing as rigorous exists to check arrangements against lawyer selfdealing. Lawyers are regulated mostly by their clients or professionalism codes. Yet ethical rules are least effective precisely where they are most needed-in local practice settings with strong structural pressures to ignore formal rules of professionalism. ${ }^{246}$

241 Scholars explain much of the variation by pointing either to nonmarket contextual factors (differing government regulatory schemes or insurance markets, for instance, or differently structured markets within given industries), or to varying effects of political and ideological influences. See, e.g., RUDOLPH J.R. PERTZ, HISTORY AS EXPLANATION: ANNALS OF AMERICAN POLITCAL ECONOMY 231 (1997) (reviewing several book-length studies offering different arguments for the effect of politics, ideology, and markets on the development of corporate govemance); MARK ROE, STRONG MANAGERS, WEAK OWNERS $48-49$ (1994) (arguing for the influence of populist politics on American corporate govemance). Other explanations include behavioral choices not explained by market forces, such as the recent interest in path dependence. See, e.g., Symposium, Path Dependency and Comparative Corporate Governance, 74 WASH. U. L.Q. 317 (1996); Millon, supra note 188, at 1025-40 (applying path dependence theory to problem of whether employment should be at-will or secured).

242 See Roe, supra note 197 , at 648-49.

243 See generally ALBERT O. HIRSCHMAN, EXIT, VOICE AND LOYALTY (1970).

244 The above discussion of clients' subjective preferences shows a weakness of the voice option. See supra Part IV.A.

245 See Roe, supra note 197, at 647.

246 Cf. William H. Simon, What Difference Does It Make Whether Corporate Managers Have Public Responsibilities, 50 WASH. \& LEE L. REV. 1697, 1701 (1993) (discussing an analogous problem of corporate managers serving owner or public interests and expressing skepticism that a "conception of the public interest" and reform of fiduciary doctrine will change behavior without structural reform). 


\section{Local Construction of Professionalism}

Codes and customs of professionalism should counteract attomeys' and judges' adherence to detrimental norms. Yet professionalism consists of much beyond codes of ethics, which themselves are often written at a level of generality to be of little use with regard to the sorts of practices regulated by norms. ${ }^{247}$ The content of professionalism is constructed in local practice contexts as well as in formal rules or bar association initiatives. "Tdeal visions of lawyering and the lawyer's role" are crucial parts of professionalism, Nelson and Trubek argue, and these visions "affect the way lawyers organize their practices and understand their everyday life."248

Conceptions of lawyer professionalism reflect "the arenas" in which they are produced, that is, the particular institutional settings in which groups construct, explicitly or implicitly, models of the law and of lawyering.... [D]ifferent groups will develop different versions of the professional ideal in response to a variety of political, ideological, and situational concerns....

Because the question of what lawyers should do is one that is addressed every day in many sites, we see the social production of professionalism as a complex process of interaction occurring in many arenas. ${ }^{249}$

Because local work settings are a primary site for the construction of the

Legal education's efforts to foster client-centered practice and teach lawyers a critical selfawareness of practice choices face the same obstacle. Recent scholarship on the theoretics of practice develop and discuss these goals and methodologies. See, e.g., Anthony V. Alfieri, Reconstructive Poverty Law Practice: Learning Lessons of Client Narrative, 100 YALE L.J. 2107 (1991); Cunningham, supra note 157; Miller, supra note 155; Symposium, Theoretics of Practice: The Integration of Progressive Thought and Practice, 43 HASTINGS L.J. 717 (1992).

247 The $A B A$ Model Code provides that a lawyer's duty "both to his client and to the legal system is to represent his client zealously within the bounds of the law." MODEL CODE OF PROFESSIONAL RESPONSIBIITY Canon 7-1 (1980). In 1983, the ABA Model Rules modified the zealous representation language. Model Rule 1.1 provides that "[a] lavryer shall provide competent representation to a client. Competent representation requires the legal knowledge, skill, thoroughness and preparation reasonably necessary for the representation." MODEL. RULES OF PROFESSIONAL CONDUCT Rule 1.1 (1997). Model Rule 1.3 requires a lawyer to "act with reasonable diligence and promptness in representing a client." MODEL RULES OF PROFESSIONAL CONDUCT Rule 1.3 (1997). The commentary adds that Rule 1.3 mandates "[a] lawyer should act with commitment and dedication to the interests of the client and with zeal in advocacy upon the client's behalf. However, a lawyer is not bound to press for every advantage that might be realized for a client." Id. at cmt. 1 .

248 Nelson \& Trubek, supra note 7, at 178.

249 Id. at 179-80; see also id. at 213 ('Lawyers' visions of their working life and working relationships are intimately related to the kinds of organizations they construct and the roles they play in political, economic, and social exchange."). 
working content of professionalism dictates, one sees that, far from professionalism rules constraining norms, norms are one way that professionalism notions are defined and put in practice. ${ }^{250}$ (Recall the attorney labeled unprofessional for complaining about ex parte contacts. ${ }^{251}$ Functional professionalism notions are one form of norms' social meaning. ${ }^{252}$ The study of practice norms responds to Nelson and Trubek's call for "workplace studies" to examine sources of professional ideology 253 and confirms their assertion that professionalism conceptions vary widely among localities despite uniform formal rules. Norms are accommodations among the multiple forces of resource availability, unworkable doctrines, conflicts among implicit public norms, variations in attorney-client relations, and lawyers' self-interests and ideological preferences. Norms are more than empirical observations of practices to mediate material constraints. They have normative content that becomes a critical part of professionalism's functional dictates. ${ }^{254}$ They are a constitutive part of professionalism content, rather than an autonomous practice governed by formal professional rules.

\section{VARIATION IN PRACTICE NORMS AND PROSPECTS FOR REFORM}

The extensive study by social scientists of legal pluralism - variation in law practice despite uniform legal rules and similar practice conditions-confirms that norms are far from uniform across contexts. ${ }^{255}$ Comparable jurisdictions can

${ }^{250} C f$. BAUM, supra note 46, at 19 (arguing that judges are not always aware of the goals that motivate them); Robert Gordon, Legal Thought and Legal Practice in the Age of American Enterprise, 1870-1920, in PROFESSIONS AND PROFESSIONAL IDEOLOGIES IN AMERICA 110 (Gerald Geison ed. 1983) (reporting that attomeys had a "deeply ingrained suspicion" of being depicted as "intellectuals producing ideology" because they "think of themselves as practical persons occupied with practical affairs"); Menkel-Meadow \& Meadow, supra note 82, at 253 (finding from empirical research a "potential gap between the factors articulated by attomeys as motivating their legal resource allocation decision ... and those factors that may actually quite latently influence those decisions"). But see generally Sunstein, supra note 70, at 918 (noting that people sometimes reject norms after "reflective judgments").

251 See supra notes 32-34 and accompanying text.

252 See supra Part V.B.

253 Nelson \& Trubek, supra note 7, at 179.

254 See HENZ \& LAUMANN, supra note 81, at 71 (arguing that attorneys in lower tiers of the bar may violate ethical rules more often on behalf of clients because clients can demand such conduct from attomeys with little economic security); see generally Nelson \& Trubek, supra note 7; Vaughan, supra note 18, at 25-34 (emphasizing the structural and contextual influences on decisionmaking).

255 See FLEMMING ET AL., supra note 16, at 1, 205-06. This has been implicit in studies of norms generally; Ellickson did not suggest that the norms employed by ranchers in Shasta County described the conduct of all ranchers. See ELLICKSON, supra note 11, at 1. 
have widely varying practices, characterized by great variations in their levels of cooperation or formality and adversarial approaches, as well as in the content of norms. ${ }^{256}$ Some practice norms that save court and attorney resources are often not products of necessity, despite the perceptions of their adherents. ${ }^{257}$

One implication of legal pluralism is the potential for change in the ways local practice groups operate and the values to which they give priority despite the behavioral, ideological, and social constraints on norm change noted above. ${ }^{258}$ (Hold aside for the moment norms that respond to resource constraints.) Coordination problems discourage individual attomeys from challenging norms alone. ${ }^{259}$ Still, legal pluralism suggests that, with relatively little change in the funding of practice settings, "norm entrepreneurs"-who typically must be leading figures, such as judges, chief prosecutors, or head defenders - can reduce the level of undesirable practice norms; they can replace the undesirable forms of cooperative and informal behavior that undercut litigant interests with more adversarial conduct that protects those interests and legal values. 260 They can encourage greater use of legal entitlements to vindicate client claims and preferences.

256 This variation is reflected in the evolution of empirical scholarship on state criminal court practice, especially by public defenders or court-appointed attomeys. An early view, not entirely discredited (especially among practitioners), suggested that defense attomeys who were regular insiders in a local court could capitalize on their close relationships with judges and prosecutors to gain maximum advantage for clients. See NARDULLI ET AL., supra note 15, at 320-21; NARDULLI, supra note 42, at 3-33; R.H. Smith \& Herbert Ehrmann, The Criminal Courts, in CRIMINAL JUSTICE N ClEVELAND (Roscoe Pound \& Felix Frankfurter eds., 1921). A second, more recent analysis characterizes such defense attomeys as "cop out artists" who sell short the interests of their clients to maintain personal advantages within the courthouse work group. See ABRAHAM BLUMBERG, CRIMINAL JUSTICE (1967); NARDULLIET AL., supra note 15, at 322-23; Jetome Skolnick, Social Control in the Adversary System, 11 J. CONFLICT RESOL. 52 (1967).

257 See Lynch, supra note 20, at 116; see also Carns \& Kruse, supra note 129, at 316-17 (describing widely different rates of plea bargaining between Fairbanks and Anchorage, Alaska, and attributing the difference largely to the chief prosecutors' differing views on the desirability of bargains rather than on resource constraints); Schulhofer, supra note 116, at 1085-86 (concluding from empirical studies that about one quarter of felony defendants would want to plead guilty even without inducements, and that $75 \%$ of felony cases could be resolved by bench trials with only small increases in judicial resources).

258 See Sunstein, supra note 70, at 909 (discussing norm entrepreneurs).

259 See Lessig, supra note 56, at 991-1016 (discussing collective action problems related to social meaning that impede norm change).

260 See FLEMMING ET AL., supra note 16, at 8 ("Work group autonomy is not inevitable, it evolves out of the policy choices of the bench, bar, and prosecutor.'); see also id. at 19 ("The leadership of individual actors and the organization of collective action, however, are the means through which contexts are created and maintained."). 
Examples abound. One can easily find practice settings in which ex parte contacts with judges are not routine. Lynch's study suggests that trial rates can increase significantly merely through the leadership of key judges in a jurisdiction. ${ }^{261}$ The study of DuPage County's criminal courts reported an "insurgent" prosecutor who withdrew key rewards for cooperative behavioropen file discovery, plea bargain discounts-and thereby forced a more adversarial practice in the jurisdiction. ${ }^{262}$ District attorneys in comparable Alaska localities implemented a statewide plea bargaining ban with different levels of commitment, resulting in very different plea bargaining rates. ${ }^{263}$ To encourage zeal by his staff attorneys, a federal public defender issued a memorandum declaring the court and federal prosecutors to be "our enemies" and reiterating a "long-standing offer" of cash rewards for attomeys threatened with or held in contempt of court. 264

Relatedly, the calculations of attorney and judicial self-interest that motivate some norms are themselves contingent. ${ }^{265}$ Some norms serve desires to save time and enjoy nonconfrontational work relations. Yet some attorneys desire more trials. Some gain fulfillment from zealously serving client interests, from fulfilling formal professional roles as advocates, ${ }^{266}$ and even from challenging

261 See Lynch, supra note 20, at 130.

One of my students spent his summer as a clerk for a municipal judge whose court had jurisdiction to conduct both civil and criminal jury trials. The student reported that his judge frequently presided over trials and hoped to set an informal record for the most jury trials supervised in a year by a municipal judge. He added that his judge disparaged another judge in nearby municipal court, who rarely has trials in his court. (The student was told by his judge that the neighboring judge had no jury trials in the first six months of the year.) The student's judge specifically reported that the neighboring judge used explicit trial penalties to discourage criminal trials, indicating a plea would receive a light sentence but a loss at trial would receive a sentence near the maximum. See Telephone Interview with Michael DeFibaugh (July 13, 1998). The contrast, assuming it is accurately reported (on some points through two or three levels of hearsay), demonstrates the considerable leeway for norm entrepreneurs within systems that likely have modest budgets. For better documented examples of judges' relative willingness to allow trials, see, for example, FLEMMING ET AL., supra note 16, at 69, $105-08$.

262 See NARDULLI ET AL., supra note 15, at chs. 5-6 (showing how norms can vary even within similar community structures, revealing that norm entrepreneurs can establish adversarial, zealous, and fairly formal practice environments even in close-knit communities).

263 See Cams \& Kruse, supra note 129, at 317 (concluding that the "most important condition" for a successful plea bargaining ban by prosecutors is "the personal decision" of "a committed policy maker" such as the district attorney).

264 See Frankel, supra note 41, at 67.

265 See Sunstein, supra note 70, at 939-47 (discussing the contingency of preferences and how "rational decision is very much a function of social norms").

266 See Menkel-Meadow \& Meadow, supra note 82, at 244 (noting that an attomey may gain reputational benefits from "pursuing reform rather than routine cases"). Both law school 
dominant practice norms. ${ }^{267}$ This raises possibilities for facilitating norm revision in local practice settings to encourage those preferences. Courts could alter reporting practices so that judges are not rewarded for moving through dockets as quickly as possible -implicitly, with as few trials as possible-but rather are encouraged to strive for disposing of some substantial portion of their cases by trials. 268 One could imagine a setting in which judges lost esteem or were otherwise sanctioned for holding too few trials, ${ }^{269}$ or in which prosecutors were disqualified from plum assignments or judicial appointments if courts found that they violated fair-trial doctrines by such actions as withholding evidence. 270

Similarly, office leaders could evaluate and promote attorneys who resolve some higher portion of cases by trial or otherwise reorganize office culture. 271 They could encourage involvement in specialized bar groups (for example, criminal defender associations) that foster zealous advocacy. Lawyers might then adopt the values of those subcultures they more strongly identify with and start resisting some norms of local practice. ${ }^{272}$ (This may make them more willing to endure personal costs, though they must also assess sanctions imposed directly on the client.) Low level staff attorneys have much less leeway to reshape

education and specialized professional associations (e.g., National Association of Criminal Defense Lawyers, National District Attomeys Association) often seek to foster such preferences and commitments.

267 See Sunstein, supra note 70, at 918.

${ }^{268}$ Cf. Resnik, supra note 35, at 379, 398-99, 404, 427 (discussing the detrimental effect of docket management techniques by federal judges in civil cases).

269 See supra note 261 (relating an anecdotal account of a local judge striving to set an informal record for holding the most jury trials in a municipal court). This should also influence judges to appoint attorneys who are willing to try cases.

270 Currently in some states, if not most, prosecutorial misconduct leading to reversible error and heightening the risk of wrongful conviction-withholding exculpatory evidence or prejudicial comments in trial-is no impediment to a judicial appointment. See, e.g., Ken Armstrong \& Maurice Possley, Break the Rules, Be Promoted, CHI. TRIB., Jan. 14, 1999, at A1 (describing several cases in Illinois of prosecutors repeatedly found to have committed such violations but who were subsequently elevated to the bench).

271 See Menkel-Meadow \& Meadow, supra note 82, at 253-54 (concluding from an empirical study that while "[l]egal services lawyers may perceive themselves as autonomous individual professionals making rational resource allocation decisions ..., much of their own task initiation may be in response to or in pursuit of bureaucratic or programmatic directives or goals"). For suggestions on maintaining zeal in a public defender office, see generally Charles Ogletree, Beyond Justifications: Seeking Motivations to Sustain Public Defenders, 106 HARV. L. REV. 1239 (1993).

272 See Sunstein, supra note 70, at 918; see also id. at 911-14 (arguing that people's "interests" and preferences are socially contingent and constructed). 
norms-recall the new lawyer who challenged entrenched ex parte contacts 273 but they can at least resist by rejecting reputation sanctions, for instance, by speaking well of those who are aggressive advocates while disagreeing with norms that undermine client or public interests. In this way lawyers can weaken norm enforcement. ${ }^{274}$

Note that most of these strategies attempt to change one mechanism that sustains norms-their social meaning. Strategies that make aggressive defense advocacy and fair prosecution (or judicial conduct to foster full and fair adjudication) have a positive meaning that undercuts opposing norms. They take away a potent enforcement tool, injury to reputation. Other enforcement mechanisms remain, certainly, so norms are hard to change. However, changes in norms' social meaning could spark productive shifts in other supporting factors - the status-quo bias of default practices, herd-behavior baselines, and then the working content of professionalism.

One must recall, however, the taxonomy of norms. ${ }^{275}$ Those norms on the left side of the continuum, motivated by resource constraints, will not be amenable to these strategies for change. Their causes are not contingent, ideological commitments, so "norm entrepreneurs" have little power to affect them. Yet those are the norms that, this Article has argued, are defensible responses to resource imperatives created by political decisions. Those are the norms that instead should prompt courts to re-evaluate legal rules. The practices that are most normatively troublesome are also those most susceptible to reform.

\section{CONCLUSION: NORMS AND PERSONAL RESPONSIBIITYY}

Strong norms affect lawyers' capacity for critical evaluation and thereby raise questions of personal responsibility. How blameworthy is one who adheres to the norms that dominate one's local culture, and that sometimes can be breached only at significant cost? The answer for attorneys practicing in normladen settings is much the same as for criminal actors in local environments that foster lawbreaking conduct. "Rotten social background" does not serve as a legal excuse for crimes. Yet one cannot avoid noting the unfairness of judging a person who was raised entirely in such a background by the same standards as a person who lived in a context that nurtures respect for law.

For a sharper comparison, consider the pervasive culture of antisemitism that

273 See supra text accompanying notes 32-34.

274 Norms may change through a "snowball effect": when enough violations of the norm occur-along with open endorsement of norm violations or condemnation of norm adherence-more people are emboldened to violate the norm, eventually abolishing it. See Hasen, supra note 12, at 2151.

275 See supra Part III.E. 
Daniel Goldhagen describes in his book on German perpetrators of the Holocaust, Hitler's Willing Executioners. ${ }^{276}$ Goldhagen argues that so many ordinary Germans participated in genocide because a long-standing "cultural cognitive model" that labeled Jews evil and subhuman made it nearly impossible for most people to avoid adopting that perspective and to see its immorality. The cultural dominance of antisemitism explains, but does not excuse, Holocaust perpetrators. The same assessment applies for the comparatively banal actions of substandard lawyering. Lawyers as groups construct norms; though norms become hard to recognize and resist at times, lawyers ultimately bear the responsibility for changing them.

Assigning moral responsibility, however, does not necessarily prescribe the most effective strategy for change. Community norms may not excuse criminal actors from bad neighborhoods, but efforts to change those norms seem to be a more promising route to preventing bad conduct than deterrence through punishment for violators. For lawyers, structural approaches for weakening bad norms are at least as promising as admonitions to follow formal professionalism dictates, or pedagogical efforts to instill habits of reflective lawyering that will themselves be shaped by norms. ${ }^{277}$ One cannot abandon holding individuals responsible for their actions, but that does not mean that urging attomeys to monitor their conduct with continual critical reflection is the best strategy for changing behavior.

The nature of legal entitlements leaves a large role for practice norms. Entitlements are available to parties but do not have to be used by them. Attomeys and judges recognize that legal processes are a scarce resource; they develop criteria on how to use them.278 The choice of how much the state, and attorneys, should favor formal legal process over informal options is a complex and value-laden decision made at the level of client representation as well as doctrine or legislation, ${ }^{279}$ particularly when conflicting policy choices compel

276 DANIEL JONAH GOLDHAGEN, HITLER'S WILLING EXECUTIONERS (1996).

277 Particularly in client counseling and clinical programs, many legal educators emphasize reflective lawyering, which entails self-evaluation of lawyering choices during and after case completion or key practice events. See, e.g., DONALD A. SCHON, THE REFLECTIVE PRACTITIONER: HOW PROFESSIONALS THINK IN ACTION (1983); Jay Feinman \& Marc Feldman, Pedagogy and Politics, 73 GEO. L.J. 875, 894 (1985) (stressing the need to teach "critical selfreflectiveness" to overcome the tendency of "[i]mexperienced lawyers ... [to] imitate and adopt prevailing practice standards when they lack confidence in their ability to evaluate critically the quality of prevailing norms"); Donald A. Schon, Educating the Reflective Legal Practitioner, 2 CLINCAL L. REV. 231 (1995).

278 See generally Simon, supra note 73.

${ }^{279}$ Cf. Peter H. Huang, A New Options Theory for Risk Multipliers of Attorney's Fees in Federal Civil Rights Litigation, 73 N.Y.U. L. REV. 1943 (1998) (discussing public interest litigation via an options theory that recognizes that litigation consists of a series of options to 
responses such as norms to allocate scarce entitlements. 280 Practice norms reveal how fragile legal entitlements and processes can be as means to serve adjudicative justice and party interests.

Not all norms are bad for clients or public interests. Practice norms addressed in this Article are suspicious because they affect many of the very entitlements intended to make the adversarial system more effective, and they affect disproportionately the most vulnerable parties. Norms mediate the same balance between competing goals of efficiency and substantive faimess that appellate courts and legislatures balance in a variety of rules and doctrines. ${ }^{281}$ Yet they resolve that tension covertly, at the level of ordinary lawyering decisions, judicial rulings, and trial court administration. 282 Practice norms sometimes strike defensible alternatives to formal rules, but the process by which they evolve is untrustworthy. Thus, attorneys have special responsibility to distinguish those instances in which norms facilitate good professional judgment and those instances in which they undermine client interests or the public justice system. The power and content of law depend upon an ongoing commitment to maintain the mechanisms and values that give it life.

continue or settle).

280 See supra Part II.C.

281 A recent example of a statute that makes explicit trade offs between efficiency and faimess or accuracy is the 1996 Anti-Terrorism and Effective Death Penalty Act, 28 U.S.C. $\$ \S 2244-2266$ (1996). Many civil procedure and evidence rules balance similar interests.

282 Cf. Fiss, supra note 64 , at 1088-89 (arguing that ADR and settlement in civil cases often undervalue public concems inherent in legal adjudication). Some attomeys are aware that norms ignore public values. See, e.g., HEUMANN, supra note 16, at 86 (showing a lawyer justifying the trial-penalty norm by noting, "I think substantial justice is worked out a good percentage of the time: you kind of reach the right results for the wrong reasons."). 
